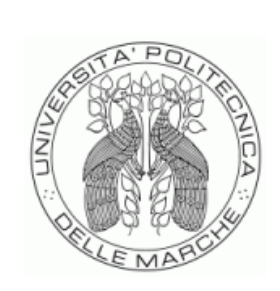

UNIVERSITÀ POLITECNICA DELLEMARCHE DIPARTIMENTO DI ECONOMIA

\title{
WHO CAPTURES WHO? \\ LONG-LASTING BANK RELATIONSHIPS \\ AND GROWTH OF FIRMS
}

Alessandro GAmbini AlBerto ZaZZARo

QUADERNO DI RICERCA n. 332

Luglio 2009 
Comitato scientifico:

Renato Balducci

Marco Crivellini

Marco Gallegati

Alberto Niccoli

Alberto Zazzaro

Collana curata da:

Massimo Tamberi 


\title{
Who captures who? Long-lasting bank relationships and growth of firms*
}

\author{
Alessandro Gambini \\ Università Politecnica delle Marche \\ Money and Finance Research Group (MoFiR) \\ CeMaFiR
}

\author{
Alberto Zazzaro \\ Università Politecnica delle Marche \\ Money and Finance Research Group (MoFiR) \\ CFESPR
}

\begin{abstract}
The theoretical literature has identified potential benefits and costs of close bank-firm relationships for both parties, suggesting possible reasons for firms being captured by banks and vice versa. In this paper we empirically explore the effects of long-lasting credit relationships on employment and asset growth of a large sample of Italian manufacturing firms in the period 1998-2003. The main findings are that relationship lending hampers the efforts of small firms to increase their size (especially in terms of employees), while it mitigates the negative growth of troubled, medium-large enterprises, thus supporting the hypothesis that small firms are captured by banks which, in turn, are captured by large firms.
\end{abstract}

JEL classification: G21; G34.

Keywords: Relationship lending, Capture effects, Firms' growth.

\footnotetext{
* We wish to thank Piero Alessandrini, Marco Lilla, Jack Lucchetti, Andrea Presbitero, Franco Spinelli, Carmine Trecroci and an anonymous referee for discussions and helpful suggestions. Our thanks also go to seminar participants at the University of Brescia. Usual disclaimer applies.
} 



\section{Introduction}

Ever since Williamson $(1976 ; 1985)$, the idea that contracts undergo a "fundamental transformation" during their life, from a competitive transaction towards a bilateral monopoly between the parties, has become familiar among economists. A typical contract to which such a fundamental transformation applies is the bank-loan contract. At the outset, both the lender and borrower have a large number of potential counterparts with which they can do business. As the lending relationship goes on, however, a two-sided dependency arises, creating some monopoly power in favour of both parties. During the lending relationship, the bank invests in human, organizational and physical relation-specific assets and gathers soft, proprietary information on the firm's creditworthiness. This boosts the value of the relationship, but can lock the bank and the firm into the relationship, the former captured by the latter and vice versa. On the one hand, the informational advantage gained by the lender makes it costly for the firm to escape from the relationship with him (Sharpe 1990; Rajan 1992). On the other, the greater the resources invested in the relationship the harder for the bank to terminate the loan contract, even when the firm is suffering and its economic prospects have deteriorated (Dewatripont and Maskin 1995; Longhofer and Santos 2000).

As in any other bargaining context, 'who captures who' depends on the relative cost of contract termination for the bank and the firm. To the extent that information problems tend to be severer in small rather than in large business lending, it can be reasonable to conjecture that banks can capture small enterprises (hereafter the BcSE hypothesis). By contrast, given that banks devote more specific resources to relationships with large rather than with small firms, one can expect that banks are, in turn, captured by large enterprises (hereafter the LEcB hypothesis).

These conjectures have found mixed, and only partial empirical corroboration in the literature ${ }^{2}$. First of all, available studies either focus on lending relationships with small businesses or consider large, publicly quoted firms, while they provide no direct indications on differentiated capture effects between

\footnotetext{
${ }^{1}$ The "Williamson transform", according to the Alchian (1987) terminology.

2 In Section 2, we provide a selective review of the empirical findings on the capture effects arising from relationship lending.
} 
small and large enterprises in homogeneous institutional environments. Second, the empirical literature primarily focuses on the impact that close bank ties have on loan contract terms and the amount of credit granted, correlations which may be strongly affected by selection effects due to the different riskiness of old and new borrowers. Third, those studies that compare the performance of bankdependent and independent firms fail to distinguish firms on the basis of their health conditions, thus not allowing one to separate the effects of informational capture from information availability and to unambiguously identify the existence and direction of capture effects.

In this paper, we consider the correlation between the length of the credit relationship with the main bank and the firm's growth rate for a large panel of Italian manufacturing firms in the period 19982003. First, we split our sample into small and medium-large firms to test the BcSE and LEcB hypotheses. Second, assuming that the growth rate of firms is positively associated with their health status, we address selection and identification problems without resorting to a straight and problematic categorization of firms into distressed and non-distressed. In particular, using quantile regressions we assess the impact of the length of bank-firm relationship on the upper and lower tails of growth distribution. Moreover, using multinomial logistic regressions and the Heckman two-step procedure: (i) we study the likelihood of bank-dependent firms growing at a positive, negative or zero rate, and (ii) we differentiate the impact of close bank ties on the firms' decision to grow or downsize from the effect on the choice of how much they want to expand or shrink. In this way, we can test whether banks are captured by large, distressed firms (LDEcB hypothesis) and, by contrast, whether they capture small, healthy firms (BcSHE hypothesis).

Consistent with the BcSE and $\mathrm{LEcB}$ hypotheses, we find that the conditional mean growth rate of small enterprises is negatively affected by the maintenance of long-lasting ties with a bank, while the growth performance of medium and large enterprises increases with the length of the relationship, although this latter effect is not statistically very significant. Furthermore, consistent with the BcSHE hypothesis we find that the positive growth of small enterprises is negatively influenced by relationship lending, while, if in trouble, small enterprises do not have any special support from their long-lasting 
lenders. By contrast, consistent with the LDEcB hypothesis, we find that when in trouble, large firms can take advantage of close ties with banks that limit their negative growth.

Besides distinguishing firms by size and the direction of their growth process, we improve upon the previous literature on firms' growth and relationship lending ${ }^{3}$ on several other grounds. First, we introduce relationship banking into a Gibrat equation. Other studies have estimated Gibrat's law augmented by capital structure and financial factors ${ }^{4}$, but no one has considered relationship banking variables. Second, while the previous literature has followed a dummy approach by distinguishing the status of firms into bank-dependent and independent on the basis of the direct and indirect ownership held by the bank in each firm, we measure relationship banking by the length of the relationship with the main bank. We can thus separate corporate governance from lending issues more neatly; moreover, our results are easily comparable with studies on financial and real effects of relationship banking. Third, following recent contributions on bank-firm relationships ${ }^{5}$, we address the possibility of reverse causality between firms' growth and bank relationships and omitted variables by using a two-stage instrumental variable estimator. Finally, we consider both the growth of firms' total assets and current employment, as in the cited literature.

The rest of the paper proceeds as follows. In Section 2, we provide a selective review of the related literature. In Section 3, we discuss the theoretical background and spell out the hypotheses to test. In Section 4 we describe the dataset, empirical model, variables and estimation methodology. In Sections 5, 6 and 7 we present our econometric results, followed by our conclusions in Section 8.

\section{Literature overview}

\footnotetext{
${ }^{3}$ See Section 2 for a review.

${ }^{4}$ See Lang et al. (1996), Heshimati (2001), Becchetti and Trovato (2002), Carpenter and Petersen (2002), Honjo and Harada (2006), Oliveira and Fortunato (2006).

${ }^{5}$ See Degryse and Ongena (2001), Fok et al. (2004), Herrera and Minetti (2007), Montoriol Garriga (2006), Alessandrini et al. (2009a, 2009b).
} 
A great number of studies provide partial evidence for possible capture effects arising from close bankfirm ties. Consistent with the BcSE hypothesis, studies concerning European countries and Japan have typically found that interest rates and required collateral on small business lending increase with the length of the bank-firm relationship (Angelini et al. 1998; Degryse and Van Cayseele 2000; Hernandez and Martinez 2006; Ono and Uesugi 2005; Ogawa et al. 2007) ${ }^{6}$. In addition, the profitability of small firms tends to be lower when they maintain exclusive relationships with few banks, thus indicating that the value created in a bank-firm relationship is appropriated by the bank and not passed along to small borrowers (Montoriol Garriga 2006). On the contrary, looking at troubled firms, other studies have implicitly rejected the hypothesis that banks are captured by small firms. Sakai et al. (2007), analysing a large panel of small Japanese firms for the period 1997-2002, found that prospective defaulters (i.e., firms that defaulted during the sample period) pay higher interest rates than survivors regardless of their age, thus indicating that banks do not have the incentive to support and subsidize (i.e., banks are not captured by) small troubled borrowers. Similarly, Brunner and Krahnen (2008) showed that in Germany the probability a pool of banks forms to revitalize distressed small and medium enterprises is greater when the firm debt is evenly distributed among a large number of banks, thus rejecting, $a$ contrario, the firm-capture-bank hypothesis for small borrowers.

In the United States as well, the informational advantage that relationship lenders get over nonrelationship lenders proves disproportionately high in small business lending. Bharath et al. (2007), for example, found that for small (large) firms the probability of obtaining a new loan from a prior lender is 63.6 (35.1) percent higher than borrowing from a new bank. Similarly, the probability of a lender extending credit to a prior small borrower is significantly higher than that of lending to a new small customer (Cole 1998). However, the bank-capture-firm hypothesis is not applicable to US small firms that seem not to suffer hold-up problems from long-lasting credit relationships, but they tend to see loan contract terms improve (or, at least, not worsen) during a relationship (Petersen and Rajan

\footnotetext{
${ }^{6}$ An exception is Harhoff and Körting (1998) who, considering a sample of small and medium German enterprises, found that as the lending relationship continues the probability of pledging collateral reduces, while interest rates do not increase.
} 
1994,;Berger and Udell 1995; Blackwell and Winters 1997; Cole 1998; Chakraborty and Hu 2006; Brick and Palia 2007) ${ }^{7}$.

Evidence on large firms is scarcer and contrasting. Some studies have focused on firm profitability of bank-dependent firms. Nakatani (1984), Weinstein and Yafeh (1998), Agarwal and Elston (2001), and Chirinko and Elston (2006) found that in Germany and Japan firms closely tied to their banks exhibit lower (or not higher) profitability. By contrast, Degryse and Ongena (2001) and Fok et al. (2004), on examining a panel of publicly listed firms in Norway and Taiwan respectively, found that exclusive relationships with banks improve firm performance. Consistent evidence on the capture of relationship lenders by large firms has emerged for the Japanese economy especially during the crisis of the 1990s. In their classical study on bank-firm relationships in Japan, Hoshi et al. (1990) found that firms under financial distress, with the operating income lower than their interest payments, experience a relatively modest contraction in their investments and sales if they belong to industrial groups including their main bank (universally known as a keiretsu). Kawai et al. (1996) reported that interest-rate premia paid by firms at the time of financial distress are significantly lower if they rely on the same largest bank lenders for at least ten years. More recently, Peek and Rosengren (2005) showed that large troubled firms with strong bank ties are more likely to obtain additional loans relative to other firms. This is especially true if the firm and the bank belong to the same keiretsu and if the keiretsu-bank acts as the main bank for the borrowing firm.

This literature, however, does not provide unequivocal evidence on the existence and direction of capture-effects in close, stable bank-firm relationships. For example, studies examining loan contract terms, although controlling for borrowers' riskiness, do not distinguish firms on the basis of their quality standing. Hence, the higher interest rate charged to small firms that are bank's clients for a long time could simply reflect a selection effect such that these firms are on average riskier than new small borrowers. In this vein, for example, banks could have a more cautious attitude towards unknown

\footnotetext{
7 However, it is worth noting that in US studies "small firms" are substantially larger (up to 500 employees) than firms classified as "small" in European studies (typically, fewer than 50 employees).
} 
borrowers and pick only high creditworthy firms or, further, banks could find it profitable not to renew loans to "young" clients who prove risky. In the first case, the higher interest rate on long-lasting smallbusiness loans would simply reflect the quality of borrowers and there would be no informational capture on the part of banks. In the second case, the positive correlation between the interest rate and the length of the relationship would even indicate that it is the banks that are captured by small old borrowers.

Similarly, to the extent that lenders can acquire private, exclusive information on borrowers as the relationship continues over time, the greater probability of large, distressed firms with close bank ties obtaining credit could simply reflect the accurate and positive assessment of firms' recovery prospects.

A few papers have considered the growth performance of bank-dependent firms relative to independent firms in Germany and Japan, consistently showing that the former do not exhibit faster growth rates. Nakatani (1984) considers the rate of growth in terms of sales values for 317 firms in the period 1974-1982 and finds that those belonging to a keiretsu do not perform better than non-member firms. Weinstein and Yafeh (1998) analyse the annual growth rate of sales of a large sample of small and large Japanese enterprises in the period 1977-1986 and classify a firm as bank-dependent if it belongs to a bank-centred financial corporate group. Once again, they can neatly reject the hypothesis that, all else equal, main bank clients grow more rapidly than other firms. Weinstein and Yafeh's results are broadly confirmed by Miarka (1999) for the period 1985-1998 with a variety of bank-relationship measures. Agarwal and Elston (2001) analyse the annual growth rate of sales for a sample of 100 large enterprises in Germany in the period 1970-1986. Even after controlling for unobserved individual effects by including fixed effects, their regression results indicate that the ownership control of the bank does not influence firms' growth (see also Elston 2002). Moreover, the existence of close ties to banks is proxied by the number of bank relationships or by a $0-1$ variable depending on the ownership stake in the firm held by the bank ${ }^{8}$.

\footnotetext{
${ }^{8}$ In a similar vein, Houston and James (2001) study the investment behaviour of bank-dependent firms and conclude that in the US "banks are unwilling to finance relatively large capital expenditures and thus bank-dependent firms must rely more
} 
In principle, if we are only willing to assume that the firms' health status is a leading factor in their growth decisions, looking at firms' growth allows one to overcome (or limit) selection problems and identify capture effects by studying the effects of close bank ties on the entire growth-rate distribution and on the positive and negative growth performance. However, the studies we cited focus exclusively on the conditional average growth rates and, like studies on loan contract terms, cannot provide unequivocal evidence about the occurrence and direction of capture effects.

\section{Hold-up and firms' growth: theoretical background and empirical predictions}

Insofar as long-lasting lending relationships allow banks to have access to private information on borrowers, bank-dependent firms should benefit from easier access to finance and display, on average, higher growth rates than independent firms. Even when hold-up problems are particularly keen, longlasting relationships facilitate information exchanges between parties, implicit contracts and intertemporal smoothing in loan terms, and should let growth opportunities be fully exploited. However, as stated above, the available evidence conflicts with this prediction.

Why should a relational bank be concerned with large investment projects and the growth prospects of their clients? This baffling question has invited several plausible answers. First, Weinstein and Yafeh (1998) suggest that main banks, as major debt holders, could be more risk-averse than other banks. Second, main banks might have an interest to collude with the firm's management which, once protected by the bank from a hostile takeover, may pursue more cautious investment policies (Chirinko and Elston 2006). Third, in order to reduce negative externalities on other borrowers or to open up new business opportunities, banks might find profitable to reveal private information about the firm for whom they are the main bank, thus dissipating the firm's crucial competitive advantages (Agarwal and Elston 2001). Fourth, the negative impact of main bank ties on firms' growth could be due to a selection bias arising from soft-budget-constraint problems. Specifically, it may be thought that bank-

on internally generated funds for these types of expenditures" (p. 349). See also Yafeh and Yosha (2003) who show that in Japan bank-dependent firms invest less in $R \& D$ than independent firms. 
dependent firms go bankrupt only rarely because they tend to be inefficiently rescued by their main bank in the hope of recovering previous loans. If this were the case, then bank-dependent firms would be observed to be weaker and growing less, on average, than firms without a main bank (Chirinko and Elston 2006).

To be sure, main bank risk aversion, collusive behaviour, conflict of interests and soft budget constraints are valid explanations for the missing link between relationship lending and growth for large firms, but seem less compelling motivations if applied to small firms whose growth should only benefit from the information disclosure triggered by close bank ties. Moreover, they do not dwell on the differences between firms that are in good standing and those in trouble, and ignore the possibility of asymmetric effects on positive and negative growth. Finally, these explanations do not contemplate the possibility of reciprocal capture effects between banks and firms tied in long-lasting relationships.

On closer inspection, however, classic hold-up mechanisms may justify differentiated effects of long-lasting bank relationships on growth by firm size and health status. Two widely held conjectures in the banking literature are that informational rents and market power of banks decrease with the borrower's size (Petersen and Rajan 1995) and that losses per dollar lent in the bankruptcy of borrowers increase with their size. Taken further, this suggests that: (i) relational banks are relatively unwilling to fund the (rapid) positive growth of small firms; (ii) relational banks have a great interest in rescuing large firms in financial distress, while they are less ready to support small, troubled firms.

The argument runs as follows. When funding the positive growth of an existing firm, the relational bank has to balance the benefit of lending to a larger client in the future with the cost of a decrease in market power over the same client and in the share of profits extractable in the credit relationship. Obviously, if the bank refuses to fund the firm's growth it risks losing the client who will search for other lenders. A relational bank will support the growth project only if the expected returns from operating with a larger firm are greater than the profits the bank is currently earning with that firm times the probability of keeping it as a client in the future. If the chances a borrower has to escape from a bank relationship decrease with its duration and with the firm's size, this means that, all else being 
equal, relational banks may find it relatively unprofitable to finance the rapid growth of small enterprises, while they have an interest in driving small firms towards growth-neutral investments.

On the other hand, the bigger the firm-client the greater the relation-specific resources (per dollar lent) the bank invests in the customer relationship and the greater the bank's interest in rescuing the firm when in trouble and limiting its negative growth (and possible failure). On the contrary, not unlike arm's-length banks, relational banks may prefer to let a small firm cut its size or even fail rather than freeze resources in a troubled relationship.

These theoretical arguments can be summarized in the following testable hypotheses:

BcSE Hypothesis. The growth rate of small enterprises is negatively or non-correlated with the length of the lending relationship with main banks.

BcSHE Hypothesis. Small, bealthy enterprises with long-lasting bank ties grow relatively less than bankindependent firms.

LEcB Hypothesis. The growth rate of large enterprises is positively or non-correlated with the length of the lending relationship with their main banks.

LDEcB Hypothesis. Long-lasting bank ties facilitate the rescue of large, distressed enterprises by limiting their negative growth.

\section{Dataset, estimated model and summary statistics}

\subsection{Data}

The whole set of firm-specific information as well as information on the duration of the credit relationship with the main bank are drawn from the Indagine sulle Imprese Manifatturiere, a survey carried out on manufacturing firms by the Italian banking group Unicredit (formerly, by Mediocredito Centrale and Capitalia) every three years. We considered the last two waves run in 2001 (covering the 1998-2000 period) and 2004 (covering the 2001-2003 period). The survey targets manufacturing firms with more than 10 employees: the universe of firms with more than 500 employees and a stratified sample of firms 
with 11-500 employees. The sample is actually fairly representative of the Italian economic structure: (1) 66 percent of firms have less than 50 employees, while 91 percent are below the threshold of 250 employees, (2) about 70 percent are headquartered in northern Italy, (3) more than 50 percent of the firms operate in traditional sectors, as defined by the Pavitt classification, while only 5 percent are hightech.

Each wave contains over 4,000 firms with almost half of the firms being replaced by new firms in each survey (rotating panel). Replacement may be due to several reasons such as firms ceasing their activity, not belonging any longer to the manufacturing sector, reducing the number of employees below 11 or simply ending their participation in the survey. Unfortunately, it is not possible to distinguish between these cases and hence control for the survival selection bias. After checking for inconsistencies, outliers and missing values, between 5,329 and 5,440 observations were available for our regression analysis. The survey data are complemented with information on the Italian banking market at the provincial level based on Bank of Italy statistics and drawn from Alessandrini et al. (2009a, 2009b) ${ }^{10}$.

\subsection{Growth model and estimation strategy}

We estimate a growth equation à la Gibrat, augmented by a learning by doing effect (Jovanovic 1982), some firm-specific controls and the length of the relationship with the main bank:

$$
\text { Growth }_{i t}=\alpha+\beta_{1} \text { Size }_{i t}+\beta_{2} A_{g e}+\beta_{3} \text { Main-bank relationship length } i t+\sum_{j=1}^{n} \gamma_{j} X_{j i t}+\varepsilon_{i t}
$$

Growth is the average annual growth rate of firm size over the survey wave period:

$$
\text { Growth }_{i t}=\frac{\left(\ln \text { Size }_{i t+2}-\ln \text { Size }_{i t}\right)}{2}
$$

\footnotetext{
9 The sample is stratified by size (distinguishing five classes according to the number of employees), geographical macroareas (Centre-North and South) and industrial macro-sectors (according to the Pavitt classification).

10 A detailed description of variables used in the analysis and their sources is reported in Table 1.
} 
where $t$ is the first year of each survey's wave. The rate of growth is computed, alternatively, in terms of current employment and total assets (see Table 1). As pointed out by Sutton (1997), when the span of time considered in the analysis is not very long, there can be systematic differences between employment- and asset-growth rates. To illustrate, the decision to either increase or decrease the number of employees imposes investments and sunk costs, especially in the presence of high employment protection and firing costs as in the Italian job market ${ }^{11}$. Therefore, it well approximates long-term projects, which are irreversible in the very short run and may have a permanent impact on the firm's main bank, calling for new financial resources and risk involvement (in the case of positive growth) or leading to loan cuts and financial losses (when the growth is negative). By contrast, the growth of total assets experienced by a firm at the end of each year, while surely reflecting the firm's market success, may be greatly affected by transitory economic conditions. When the asset-growth rate is averaged over a short time interval (in our case only a three-year period) the transitory element can be predominant and what matters is the flexibility of financial resources guaranteed by banks, rather than banks' willingness to support a stable, long-term investment project.

\section{[Insert table 1]}

Equation (1) is estimated for the whole sample and for the subsamples of small and medium-large firms. We follow the size classification adopted by the European Commission during our period of analysis according to which those firms with fewer than 50 employees and total assets less than 5 million euro are small, and the others medium-large ${ }^{12}$. On average, small firms increased their employment at a yearly rate of 1.2 percent, less than medium and large firms (1.9), while in terms of assets the growth was 4.4 percent for small firms and 3.1 for medium-large firms (Table 2).

\footnotetext{
${ }^{11}$ Statistics on the OECD Employment Protection Law Index (OECD 2004) concerning the difficulty of dismissal indicate that Italy is one of the countries with the strictest labour protection laws among OECD members, unlike English-speaking countries which have the least restrictive legislation.

12 This definition of small firms has been replaced by Recommendation 2003/361/EC (May 2003) by which the Commission raised the total asset threshold to 10 million euro.
} 
We first focus on the effects of long-lasting bank relationships on the conditional-on-covariates mean of the firms' growth rate by running both OLS and instrumental variable estimates. Second, we model the entire growth rate distribution by running quantile regressions. In this way, we can assess the existence of asymmetric effects of the credit relationship duration in the lower and upper tails of growth distribution, and hence directly test the BcSHE and $\mathrm{LDEcB}$ hypotheses. Third, we focus on firms' employment-growth rate to assess whether enduring bank ties have different effects on the likelihood of firms increasing or reducing employment and on the intensity of positive and negative growth performance. In order to address these questions we run multinomial logistic regressions for a categorical variable distinguishing firms that increase, decrease or leave unaltered the number of employees during the survey period, and estimate two selection models by following the two-stage Heckman procedure for positive and negative growth rates, respectively.

\subsection{Explanatory variables}

\subsubsection{The length of the bank relationship}

The closeness of a bank-firm relationship is not an easy phenomenon to measure (Boot 2000). A proxy for relational lending widely used in the literature is the span of time since when the firm and its main bank were tied, the basic idea being that the longer the relationship, the greater the availability of proprietary soft information and the specific resources invested by the parties in the relationship, and the more difficult it is for the bank and the firm to escape from the relationship (Petersen and Rajan 1994, Berger and Udell 1995, Degryse and Van Cayseele 2000, Ongena and Smith 2001, Elsas 2005).

In the Unicredit survey, firms are asked for how many years they have borrowed from the current main bank, that is from the bank that holds the largest share of the firm's debts. The question explicitly refers to the last of the three years covered by the survey, and therefore the responses cannot be directly used to explain firm growth during the three-year period. In order to antedate these responses to the first year of the survey period we consider as relational only those ties between a firm and its main bank lasting for more than three years. In particular, assuming that firms have not changed their 
main bank during the three-year survey period, the duration of the credit relationship is computed as follows:

$$
\text { Duration }=\left\{\begin{array}{lc}
0 & \text { if Credit length } \leq 3 \\
T=(\text { Credit length }-3) & \text { if Credit length }>3
\end{array}\right.
$$

where Credit length is the firm's response to the survey question. Thus defined, the average length of the credit relationship with the main bank is about 14 years, and it is statistically greater for medium-large enterprises (14.3 years) than for small ones (13.3) at any conventional level of significance. Assuming that the marginal effects of main-bank relationships on firms' growth are decreasing, in the regression analysis we consider the logarithmic transformation of Duration. To be precise, in equation (1) Mainbank relationship length is given by $\ln (1+\mathrm{D}$ uration $)$.

\section{[nsert Table 2]}

It is worth noting that in each survey firms are also asked with how many banks they were operating with at the end of the survey period and what was the share of the debt provided by the main bank. However, to antedate these responses to the beginning of the growth period it is not sufficient to assume that the identity of the main bank is the same, as for Duration, but one should also assume that the importance of the main bank and the number of non-main banks with which the firms do business are unchanged during the survey period. As these assumptions are much less reliable than that on the main bank identity, in our analysis we focus only on the length of the credit relationship.

\subsubsection{Control variables}

As in classical Gibrat regression models, the two main control variables are the initial size of the firm and its age. In accordance with the growth variables, Size is measured alternatively in terms of the firm's employees or assets value, in logarithm, at the beginning of the growth period. Age is computed as the logarithm of the number of years from the firm's inception to the time of the survey. Gibrat's law predicts that the firm's growth is not significantly affected by its initial size. By contrast, a negative significant impact of Size and Age on Growth would indicate that Gibrat's law is violated, while 
providing support to learning-by-doing models, predicting that well-managed firms grow rapidly and survive, while inefficient firms choose to contract their size or exit the market (Jovanovic 1982). As reported in table 2, the average firm in the sample has 105 employees and assets of 21.1 million euro; small firms are usually younger (23 years old) than medium-large firms (28).

Then we control for a set of financial and non-financial firm characteristics that are expected to influence growth rates. First, we consider the availability of internal and external financial resources. The former is proxied by the ratio of cash flow to total assets (Cash flow) and by a dummy variable that takes the value of 1 if the firm belongs to a formal corporate group and 0 otherwise (Group). A positive significant correlation between cash flow and growth is usually interpreted as firms being financially constrained on the credit markets (Carpenter and Petersen 2002). Group, instead, captures the effect that access to the capital market internal to the group has on the firm's growth rate. If the internal capital market allocates resources to sound firms efficiently, Group is expected to have a positive sign. On the contrary, if the internal capital market is used for incentive purposes (Rajan et al. 2000) or to drain resources out of affiliated firms to the benefit of controlling shareholders at the parent holding (Johnson et al. 2000), the coefficient on Group may also assume negative and significant values.

Access to external finance is proxied by the ratio of firms' debts to total assets (Leverage). This index is ambiguously associated with the firm's growth. From a theoretical point of view, the literature on the optimal capital structure gives good reasons to predict that, in the presence of asymmetric information and transaction costs, Leverage could be correlated both positively and negatively with a firm's profitability and growth prospects (Jensen and Meckling 1976; Ross 1977; Stulz 1990). Moreover, the leverage ratio contains information not only on the firm's optimal capital structure, but also on its riskiness, actually reflecting both the factual and potential access to external finance. Hence, not surprisingly, empirical studies have found positive, negative and non-significant correlations between Leverage and Growth (Opler and Titman 1994; Lang et al. 1996; Heshmati 2001; Becchetti and Trovato 2002; Honjo and Harada 2006). 
Other controls concern the firm's propensity to export and innovate. The former (Export) is measured by a dummy variable that takes the value of 1 if the firm exports part of its production in the last year of the survey and 0 otherwise. The latter $(R \& D)$ is measured by a dummy variable that takes the value of 1 if the firm made R\&D investments during the three-year survey period and 0 otherwise. Both Export and $R \& D$ are expected to be positively correlated with the firm's growth.

For robustness, in some specifications we also control for the mode of growth, the concentration of the local credit market and the "localism" of the main bank. We build: (1) a dummy variable $(M \& A)$ taking the value of 1 if the firm grows by merging or acquiring other firms during the survey period and 0 if it grows only internally; (2) the Herfindahl-Hirschman index calculated in terms of the share of branches at the provincial level; (3) a dummy variable, Local bank, taking the value of 1 if the firm's main bank is headquartered in the same province as the firm's official headquarters.

Finally, we code dummies to control a set of fixed effects accounting for the industrial sector (Industry), the firm's geographical location (Area) and the economic cycle (Year).

\section{Long-lasting bank ties and the firm's average growth rate}

\subsection{OLS estimations}

Table 3 reports OLS results for the regression model (1) relative to the overall sample (Panel A) and the two subsamples of small and medium-large enterprises (Panels B and C), using both employment- and asset-growth rates as dependent variables.

\subsubsection{Long-lasting bank ties}

With regard to our key explanatory variable, if we look at the whole sample, the impact of the length of credit relationship with the main bank on the firm's growth rate is not significantly different from zero, regardless of the measure of growth we adopt. At first sight, this finding seems to be in line with evidence for Germany and Japan discussed in Section 2, suggesting that firms are neither sustained nor 
impeded by their main banks in their growth objectives. However, things change when we split the sample into small and medium-large enterprises.

Consistent with the BcSE hypothesis, when we consider small firms, the length of the main-bank relationship proves negatively correlated to employment- and asset-growth at 5 percent level of significance. The economic impact is similar in magnitude and is robust to further controls for the mode of growth, market concentration and main bank "localism". To illustrate, in specifications (5) and (6) an increase in Main-bank relationship length from the $25^{\text {th }}$ to the $75^{\text {th }}$ percentile of its (sub-sample) distribution causes the average firm to decrease its employment (asset) growth from 1.37 (4.59) to 0.95 (3.84) percent.

Similarly, the LEcB hypothesis cannot be rejected by OLS regressions. In fact, in the case of medium-large enterprises, the average growth rate of total assets as well as the increase (or reduce) the number of employees is not affected by Main-bank relationship length whose estimated coefficient (positive in sign) is statistically not different from zero. This is consistent with the idea that relational banks cannot thwart the growth objectives of large borrowers, for whom the threat of switching to another lender is a credible weapon to obtain adequate financial support from the main bank.

[Table 3 around here]

\section{B. Gibrat's law and other control variables}

The first result that clearly emerges is violation of Gibrat's law: in other words, the growth rate of firms is not independent of their initial size. Specifically, firm size at the beginning of the period does negatively and significantly influence, at the 1 percent level, employment- and asset-growth rate. Interestingly, although our data do not allow us to consider the well-known survival selection bias ${ }^{13}$, Gibrat's law does not hold either in the small-firm subsample, where the effect of firm size on the likelihood of surviving should be definitely lower than for large firms.

\footnotetext{
13 According to the survival selection bias, the negative impact of the initial size of firms on their growth rate could be due to the fact that large, inefficient firms are more likely to survive than small, inefficient firms, which are therefore not observed and are excluded from the sample.
} 
Secondly, in accordance with Jovanovic's theory of learning-by-doing, we find a negative relationship between growth and Age especially for the asset-growth rate of small firms. The joint negative sign of Size and Age variables is in line with much of the empirical literature testing Gibrat's law (Evans 1987; Hall 1987; Dunne et al. 1989; Dunne and Hughes 1994).

As for the capital structure variables, the positive and highly significant sign of Cash flow indicates the existence of financial constraints to firm growth (Carpenter and Petersen 2002). The coefficient of Cash flow is always significant at the 1 percent level and the marginal impact is unexpectedly greater in the subsample of medium-large than small enterprises. The leverage ratio too has a positive effect on firms' growth rate, but the magnitude of coefficients is lower than in the case of internal cash flow, suggesting the existence of asymmetric information in capital markets and of a pecking order of corporate financial sources (Ross 1977, Myers and Majluf 1984).

The importance of access to financial resources internally produced is confirmed by the positive correlation between Group and growth rate. The favourable effect of group membership is limited to the growth rate of employees, and it is more robust in the case of small enterprises.

As expected, both firm openness to international trade (Export) and investment in research and development activities $(R \& D)$ are significantly and positively associated to growth, especially when measured in terms of assets and in the case of small firms.

Finally, in specifications $3-4,7-8$ and $11-12$ we add three more control variables for merger and acquisitions, credit market concentration and main bank's location. As expected, firms involved in M\&A deals grow more, on average, than firms deciding to increase their employment and asset size on the inside only ${ }^{14}$. By contrast, operating in a more concentrated credit market and borrowing from a main bank headquartered locally does not have any significant impact on firms' growth.

\subsection{Instrumental variable estimations}

\footnotetext{
${ }^{14}$ It is worth noting that violation of Gibrat's law does not stem from the presence of M\&A (Ijiri and Simon 1977).
} 
Reasonably, there are concerns that the length of the main-bank relationship can be correlated with the error term in the regression, producing biases and inconsistency in the ordinary least squares estimations. First, there can be problems of reverse causation with firms' growth prospects influencing the duration of ties with the main bank. For example, a firm that is planning future growth could decide to change its main bank in order to escape potential hold-up problems or, on the contrary, it can start to build a stable relationship in order to pass soft information to the bank. In turn, anticipating a firm's troubles (successes), the bank can interrupt (intensify) the lending relationship. Second, the length of the credit relationship with the main bank could mismeasure the exclusiveness and extension of the bank-firm relationship (which is the true explanatory variable for firms' growth) causing Main-bank firm relationship to be negatively correlated with the disturbance $\varepsilon_{i t}$ in regression (1). Third, it is reasonable to believe that the number of years that a firm has operated with the same main bank and the decision to increase its size may be affected by some common unobserved factors like the attitude to risk or the self-confidence of the owner/manager.

In order to address the problem of estimation bias in OLS we run instrumental variable regressions following a two-stage procedure. In the first stage we regress Main-bank relationship length on the variables in equation (1) plus a set of excluded instruments uncorrelated with Growth. In the second stage we estimate equation (1) with the fitted values for Main-bank relationship length from the first-stage regression coefficients.

Following a consolidated literature (Guiso et al. 2004; Herrera and Minetti 2007; Alessandrini et al. 2009a, 2009b) we use two groups of instrumental variables. One group captures the dynamics of bank branches in local markets during the period preceding our analysis: (i) the annual average number of branches opened by entrant banks in the province where the firm is headquartered during the period 1991-1998 (New branch entrants) ${ }^{15}$; (ii) the average number of new branches opened by incumbents net of

\footnotetext{
15 New branch entrants and New branch incumbents consider the absolute number of new branches opened in a province. For robustness we also considered instruments where new branches are normalized, alternatively, to the population or total
} 
closed branches in the firms' province in the same period (New branch incumbents). The other group of instruments measures the structure of local banking markets in 1936, when the Italian government passed a strict entry regulation that tightly constrained the opening of new branches in the provincial market until the late 1980s: (iii) bank branches per 10,000 inhabitants in the province (Branches); (iv-v) the share of branches owned, respectively, by saving and cooperative banks in the province (Saving banks and Cooperative Banks).

As noted by Herrera and Minetti (2007), there are no clear priors on the correlation sign between these instruments and the length of the credit relationship with the main bank. First, the opening of bank branches in provinces where saving and cooperative banks were few in number in 1936 proceeded at a slower pace until the late 1980s and then accelerated (Guiso et al. 2003). Second, as the recent literature suggests ${ }^{16}$, increased competition in the local credit market has an ambiguous effect on the exclusiveness of bank-firm ties.

\section{[Insert Table 4]}

Results of IV estimations and diagnostics on significance, validity and the relevance of excluded instruments and exogeneity of Main-bank relationship length are reported in tables 4 and 5. Looking at the Sargan test, the validity of instruments is clearly verified: the null hypothesis of valid over-identifying restrictions is never rejected at a high confidence level, indicating that none of the instruments are correlated with the error term in the structural equation and that they are correctly excluded from its estimation. For whole-sample specifications (columns 1-4), F-statistics on the excluded instruments in the first-stage regression allows us to reject the null that the instruments are jointly insignificant at 5 percent significance level. In the other specifications, the combination of instruments that are jointly significant differs by sub-subsample. For example, in the case of small firms (specifications 5-8) when

branches in the province (Herrera and Minetti 2007; Alessandrini et al. 2009a, 2009b). Estimated coefficients are substantially unaltered, while the F-statistics on excluded instruments indicates a worsening of their significance.

${ }^{16}$ Boot and Thakor (2000), Dell'Arriccia and Marquez (2004) and Hauswald and Marquez (2006) offer classical arguments for a positive correlation between competition and relationship lending, while Presbitero and Zazzaro (2009) present evidence for Italy. 
we limit instruments to Branches, Saving banks and New branch entrants the F-test indicates rejection of the null at 5 percent level. However, for the sake of comparison, and given that point estimates of coefficients are pretty similar in magnitude and significance, we opted to maintain the same set of instruments through all the specifications.

Significance apart, the value of the first-stage F-statistics is quite far from the critical values of 10.83 and 4.84 tabulated by Stock and Yogo (2005) for the strong instrument tests based, respectively, on the two stage least square (TSLS) coefficients relative bias and the limited-information maximum likelihood (LIML) significance-level distortion, in the case of a single endogenous explanatory variable and five instruments. This indicates that the instruments are weakly relevant to predicting Main-bank firm relationship ${ }^{17}$. When the excluded instruments are valid, but only weakly correlated with the endogenous explanatory variables the IV estimates are known to be biased in the same direction as OLS (in our case, the bias of estimated IV coefficients is only 50 percent lower than the bias of OLS coefficients), and estimates may not be consistent (Chao and Swanson 2005). Moreover, with weak instruments the IV-estimated standard errors are too small, tests of significance are distorted and confidence intervals are wrong (Andrews and Stock 2005; Murray 2006). Hence in table 4 we report point estimates, while confidence intervals which are robust on the strengths of instruments are reported in table 5.

\section{[nsert Table 5]}

As $t$-tests and Wald tests based on the LIML estimator are more robust to weak instruments than those based on the TSLS estimator, i.e., as the maximal size of distortion in significance level for tests is lower in regressions using the former estimator, in table 4 we report results based on both LIML and TSLS, and p-values from the standard $t$-test and the conditional likelihood ratio (CLR) test proposed by Moreira $(2003)^{18}$. Moreover, as hypothesis testing with weak instruments is especially well developed

\footnotetext{
17 A similar indication of weak instrument problems for the length of the bank relationship is provided by the study of Herrera and Minetti (2007) on the likelihood of firms adopting innovation. However, as they use non-linear TSCML regressions for which test for weak instruments are not available, they do not provide weak-instrument-robust inference.

18 Inference on coefficients of Main-bank relationship length based on the Anderson-Rubin (AR) and the LM tests provide similar results (see Table 5). The only differences worth noting with regard to the AR tests are: (i) the non-significant impact
} 
(and coded in Stata routines by Mikusheva and Poi (2006)) for models with independent identically distributed homoskedastic normal errors, unlike in OLS regressions we assume that the error term in the structural equation (1) is conditionally homoskedastic ${ }^{19}$.

Albeit with some differences with respect to OLS results, IV estimations tend to validate both BcSE and LEcB hypotheses. In particular, the non-significance of coefficients of Main-bank relationship length in the whole-sample specifications seems to be driven by the opposite effects that enduring credit relationships with main banks have on small and medium-large enterprises. Even after controlling for omitted variables and endogeneity of the duration of credit relationships, close bank ties prove to be a serious obstacle to the long-run employment growth projects of small firms. The estimated coefficient of Main-bank relationship length is significant at the 5 percent level as in OLS regressions, both using the standard t-test and the CLR test (and at the 1 percent level considering the LM test; see Table 5). However, point estimates are much higher than in OLS, especially when we use the LIML estimator, even if the weak-instrument-robust confidence intervals constructed from CLR, AR and LM tests are very ample, indicating that the magnitude of coefficients of IV estimations are not very informative. Looking at asset growth, the effect of close bank ties is still negative but, after instrumenting, p-values associated to coefficients are slightly larger than 10 percent.

With regard to medium-large enterprises, IV estimations provide statistically more significant evidence of a positive correlation between an exclusive credit relationship and growth (see columns 912). This is especially true if growth is measured in terms of total assets, suggesting that long-lasting ties with the main bank prove to be helpful to take advantage of (to tackle) unforeseen opportunities (downturns), providing financial flexibility to large enterprises.

of Main-bank relationship length for asset growth of medium-large enterprises; (ii) the rejection at 10.4 percent level of significance of a null correlation between Main-bank relationship length and the average conditional asset-growth rate for the whole sample.

${ }^{19}$ However, results of IV regressions remain practically identical if we compute standard errors robust to heteroskedasticity and abandon weak-instrument-robust inference. 
Finally, it is worth noting that while the violation of Gibrat's law seems to be confirmed by IV regressions, the coefficient of Age tend to lose statistical significance, and for small firms also assumes a positive $\operatorname{sign}^{20}$.

\section{The effects of long-lasting bank ties on growth rate distribution}

From the previous analysis, we can draw the following conclusions: long-lasting bank ties have an adverse, significant impact on the average growth rate of small firms, while they have a favourable or neutral effect on the growth of medium-large firms. These results are consistent with the BcSE and LEcB hypotheses, that is with the idea that, on average, small firms are captured by main banks, which in turn are somehow captured by medium and large firms.

However, looking at the effect of the length of credit relationships on the conditional mean of firms' growth rates, we fail to test whether long-lasting bank ties produce asymmetric effects on positive and negative growth of small and large enterprises, as is argued in the BcSHE and LDEcB hypotheses. Put differently, the focus on averages means that we cannot rule out the possibility that it is selection effects rather than capture effects which drive the missing or negative nexus between relationship banking and firms' growth.

To address this issue and better appreciate "who captures who", in this section we present results from quantile regressions of small- and large-firms' growth rates. With quantile regression we can model the entire distribution of firms' growth rates and verify the existence of an asymmetric correlation with Main-bank relationship length at the lower and upper tails of employment or asset growth distribution. If this were the case - and if the troubled, declining firms were concentrated at the lower tail and the healthy, growing firms at the upper tail, we could gain more cogent evidence on the direction of the capture effects.

\footnotetext{
${ }^{20}$ The change of sign for the coefficient of Age in IV estimations is consistent with results found by Herrera and Minetti (2007).
} 
From the unconditional cumulative distribution of employment- and asset-growth rates some interesting results emerge (Figure 1). First, growth distributions are skewed to the right, especially the growth rate of small-firm's employees. In this case, the skewness coefficient is 0.87 , with 34 percent of sampled firms showing a positive growth and a large proportion of observations (45 percent) concentrated at the zero-growth median value. For medium-large firms, 28 percent of the sample experienced zero growth in the three-year survey period, while 26 percent experienced negative growth, 46 percent positive. In the case of growth of firms' asset value, as expected we observe no zerogrowing firms: 61 (60) percent of small (medium-large) firms grew positively while the remaining 39 (40) percent reduced their asset-size.

\section{[nsert Figure 1]}

In Figure 2(A-D) we display quantile regression results for length of Main-bank relationship and the seven other control variables - with the exclusion of the intercept, area-, industry- and time-dummies -, where we plot the percentiles on the horizontal axis and the conditional-on-covariates impact of a oneunit change of the exogenous variable on firms' growth rate on the left vertical scale. In each of the panels we report: (1) the estimated coefficients from the 100 quantile regressions of the 100 percentiles of Growth as the solid line; (2) the conventional 90 percent confidence intervals for quantile coefficients as the shaded gray area; (3) the OLS estimates of the conditional mean effect as the horizontal dashed line; (4) the 90 percent confidence intervals for the mean effect as the two horizontal dotted lines.

\subsection{Long-lasting bank ties}

Consider small enterprises first (Figures 2A and 2C). Because of the grand mass of zeros in the central part of the unconditional distribution of the employment-growth rate, for regressions from the $29^{\text {th }}$ to the $57^{\text {th }}$ percentiles we cannot obtain iterative convergence. At lower percentiles, broadly corresponding to small firms growing negatively, enduring main-bank ties are not significantly correlated with firms' growth. By contrast, starting from the $58^{\text {th }}$ percentile, where the growth rate assumes positive values, the effect of long-lasting bank ties becomes negative and statistically significant at the 10, 5 or 1 percent 
levels ${ }^{21}$. In particular, close bank ties have a negative impact, which is significant at the 10 percent level on almost all the conditional percentiles from the $58^{\text {th }}$ to the $97^{\text {th }}$, and at the 5 percent level for the farthest part of the distribution. Therefore, an increase in Main-bank relationship length causes the upper tail of the conditional distribution of employment growth to shift to the left. Consistent with the BcSHE hypothesis, this suggests that the growth of small, healthy firms is lower if they have been clients of the same main bank for a long time, during which the firm has been informationally captured by the main-bank, losing the possibility to apply for loans to other lenders at a fair price. The adverse effect of long-lasting bank ties increases at the higher growth percentiles, reaching, at the $98^{\text {th }}$ percentile, almost six times the average effect found in the OLS estimation.

\section{[Insert Figure 2]}

The asymmetric impact of enduring credit relationships on small-firm growth, implicit in the BcSHE hypothesis, is broadly confirmed in the quantile regressions of the growth rate of total assets (Panel C). The quantile point estimate of the Main-bank relationship length coefficient is continuously decreasing in magnitude across the percentiles of the conditional asset growth distribution, becoming lower than the OLS estimates of the mean effect after the $63^{\text {th }}$ percentile and with the largest effects on the upper decile (the coefficient is -0.313 at the $97^{\text {th }}$ percentile) ${ }^{22}$. From the $61^{\text {th }}$ and up to the $97^{\text {th }}$ conditional percentiles the negative impact of long-lasting bank ties is statistically significant even at the 1 percent level. However, unlike the case of employment growth, small firms at the very lowest percentiles of asset-growth distribution (that is observations from $5^{\text {th }}$ up to the $7^{\text {th }}$ percentiles) seem to benefit from the bank relationship, reducing their negative growth.

Figures 2B and 2D present quantile coefficients for Main-bank relationship length concerning the medium-large-firm subsample. In this case, results are only partly in accordance with the LDEcB hypothesis. Consistent with the idea that large, distressed firms with long-lasting ties with a main bank are more likely to find financial support than bank-independent firms, quantile point estimates at the $5^{\text {th }}$

\footnotetext{
${ }^{21}$ Coefficients at the $73^{\text {rd }}$ and $85^{\text {th }}$ percentiles are not significant at the 10 percent level, but at a slightly higher level, while coefficients at the last two percentiles are very large in magnitude but statistically insignificant.

22 In this case, no problem of iterative convergence arises and we obtain point estimates for all the percentiles.
} 
up to the $17^{\text {th }}$ percentiles of employment growth distribution are positive and significant at least at the 10 percent level - where in the unconditional growth distribution firms with average growth rates between -9.1 to -2.8 percent are concentrated - with a coefficient of 0.119 for the $5^{\text {th }}$ percentile, i.e., almost 9 times the OLS coefficient of 0.014 . However, for much of the growth distribution ${ }^{23}$, and for the conditional .1median, quantile estimates are practically identical to OLS estimates in magnitude and significance, suggesting that the positive growth of medium and large firms is neither hampered nor stimulated by long-lasting relationships with main banks.

When we look at the asset growth rate, Main-bank relationship length does not seem to have any statistically significant impact on its conditional distribution. The sign of estimated coefficients is positive across almost all the percentiles, with a size similar to the OLS estimates of the mean effect, but with a statistical significance always higher than 10 percent. Therefore, in this case we find no clear evidence confirming the LDEcB hypothesis or the main-bank's capture by large enterprises.

\subsection{Control variables}

Moving on to the other control variables, we have the confirmation that the determinants of positive and negative firms' growth rates are distinct. This holds especially for the growth of employment and is consistent with the idea that change in the number of workers is a planned project entailing irreversible organizational investments in the very short run and sunk costs. If we look at the small-firm subsample (Figure 2A), Age, Leverage, Export, Group and $R \& D$ have significant effects on the upper tail of the Growth distribution (which includes firms with growth rates greater than zero), but not on its lower tail. By contrast, the variables influencing Growth at the lower percentiles are only Size and Cash-flow, for which quantile coefficients are quite different from those obtained by the conventional OLS confidence intervals. For medium-large firms (Figure 2B), we find similar trends in coefficient significance across percentiles, but in magnitudes quantile point estimates broadly fall within the confidence intervals of OLS estimations.

\footnotetext{
${ }^{23}$ Given the lower number of observations bounded to zero, we can run quantile regression across all the percentiles.
} 
For the asset-growth rate, quantile results at the lower and upper tails of Growth distribution deviate to a lesser extent from the conditional mean effects of the OLS estimates. For small firms (Figure 2C), it is only Leverage which moves well beyond the least squares, assuming opposite signs at the lower and upper tails of Growth distribution in accordance with the diverse interpretation (firm's riskiness or degree of access to external finance) attributable to this variable. For medium-large firms, besides Leverage, appreciable disparities between quantile and OLS regressions emerge with regard to firms' age, which has a negative impact on Growth only at the upper percentiles, and for firms' belonging to a group, which stimulates both positive and negative asset-growth rate, making Growth distribution more spread around the mean.

\section{Long-lasting bank ties and the likelihood of firms' employment growth or decline}

As clearly testified by many zero-employment-growth firms, the decision to modify the number of employees can be conveniently separated into two conceptually distinct choices: first, the choice of whether to recruit new (dismiss) personnel (hereafter, the occupational-changing choice); second how many workers to add to (fire from) the workforce (the occupational-intensity choice). It is not unreasonable to believe that the capture effects manifest a stronger influence on the modification choice than on the intensity choice. In this vein, the BcSHE and LDEcB Hypotheses should be reformulated as follows:

BcSHE II Hypothesis. Small, healthy enterprises with long-lasting credit relationships are less likely to recruit new workers, and if they do it is at a lower (or not higher) rate.

LDEcB II Hypothesis. Large, distressed enterprises with long-lasting credit relationships are less likely to dismiss workers, and if they do it is at a lower (or not higher) rate.

\subsection{The occupational-changing choice}

In order to investigate the effects of the length of credit relationships on the occupational-changing choice, we build a new categorical variable, Growth_123, assuming the value of 1 if firms hire workers during the three-year survey period, the value of 2 if firms leave the number of workers unaltered and 3 
if firms decrease their employment-size. As the occupational-changing choice has no natural ordering, we resort to multinomial logistic regressions to estimate the likelihood of the firm choosing one of the three options.

We assume that each firm $i$ attaches a random utility $U_{i j}=x_{i j}^{\prime} \beta+\varepsilon_{i j}$ to the alternatives $j=1,2,3$ of hiring, maintaining or firing workers. In this case, the likelihood of the firm choosing alternative $j$ is equal to the likelihood of this alternative yielding the maximum utility among all the other alternatives $k \neq j:$

$$
\operatorname{Pr} o b\left(\text { Growth_123 } 3_{i}=j\right)=\operatorname{Pr} o b\left[x_{i j}^{\prime} \beta+\varepsilon_{i j}>\max _{k \neq j}\left(x_{i k}^{\prime} \beta+\varepsilon_{i k}\right)\right]
$$

Assuming that the random terms $\varepsilon_{i j}$ are independent and identically distributed with log-Weibull distribution, we obtain the multinomial logit model (Greene 2003):

$$
\operatorname{Prob}\left(\text { Growth_123 } 3_{i}=j\right)=\frac{\exp \left(x_{i j}^{\prime} \beta\right)}{\exp \left(x_{i 1}^{\prime} \beta\right)+\exp \left(x_{i 2}^{\prime} \beta\right)+\exp \left(x_{i 3}^{\prime} \beta\right)}
$$

As (5) makes clear, the independence of $\varepsilon_{i j}$ causes the odds ratio $P_{j} / P_{k}$ to be independent of the other alternatives. For the type of decision we analyze, i.e., whether to change the firms' employment-size, the assumption of independence from irrelevant alternatives (the IIA property) seems not to be very restrictive. When boards are called to decide on the change of firm size it is reasonable to assume that what is at stake is the option to recruit (dismiss) new personnel versus the alternative to continue the business with the same number of employees at the moment of the decision, while the option to dismiss (recruit) workers is irrelevant given the positive-health (distress) conditions of the firm. In confirmation of this conjecture, the Hausman-type test for the IIA property never rejects the null that the parameters from the restricted model obtained by eliminating one alternative from the choice set are not systematically different from parameters from the unrestricted model contemplating all the three growth alternatives (see Table 6) ${ }^{24}$.

\footnotetext{
${ }^{24}$ The results reported in table 6 refer to the generalized version of the Hausman test obtained by using seemingly unrelated estimations (i.e. by using the suest command of Stata).
} 
[Insert Table 6]

In table 6 we report multinomial-logit-regression relative risk ratios using the zero-growth option $($ Growth_123 = 2) as base-choice. Consistent with BcSHE and LDEcB mark-II hypotheses, the longer the duration of the credit relationship with the main bank, the lower the probability that small firms decide to hire new workers and the lower the probability that medium-large firms decide to dismiss part of their workforce. More specifically, a one-standard-deviation increase in Main-bank relationship length causes an almost 13 percent decrease in the odds that a small firm experiences a positive employmentgrowth rather than maintaining its size unaltered, while with an identical increase of Main-bank relationship length the odds that a medium-large firm fires workers rather than maintain their workforce decrease by almost 14 percent. On the contrary, long-lasting bank relationships do not seem to provide small firms with special support when they are in trouble, as a relative risk ratio non-significantly different from 1 in the "negative versus zero growth" specification (column 2) clearly indicates.

In the last part of table 6 we report the theoretical probability of the average firm increasing, decreasing and maintaining the level of occupation unaltered when the duration of credit relationship with the main bank is equal to, respectively, the $25^{\text {th }}$ and $75^{\text {th }}$ percentiles of its (sub)sample distribution. For the average small firm, such an increase in Main-bank relationship length would reduce by 8.4 percent the probability of hiring new workers (from 0.35 to 0.32 ), while the probability of zero-growth would be 5.6 percent greater ${ }^{25}$. By contrast, the probability of medium-large firms expanding their workforce is broadly the same regardless of the length of credit relationships with the main bank, while the probability of dismissing workers and shrinking their activity would be -10.6 percent lower (decreasing from 0.27 to 0.24 ), to the benefit of an 8.6 percent higher probability of zero-growth (rising from 0.24 to 0.26$)^{26}$.

With regard to the other covariates, it is worth noting that in both sub-samples, the greater the initial firm size the greater the odds that firms experience subsequent changes (either positive or

\footnotetext{
${ }^{25}$ With Main-bank relationship length at the $90^{\text {th }}$ percentile, these changes would reach, respectively, -11.3 and 8 percent.

${ }^{26}$ With Main-bank relationship length at the $90^{\text {th }}$ percentile, medium-large firms would decrease (increase) the likelihood of firing (maintaining unaltered the number of) workers by -13.7 (11.3) percent.
} 
negative) in size, while Age has no significant effect on the odds ratios, except for large firms in the “negative versus zero growth" specification. However, of great importance for occupational-changing choices is cash flow availability. The odds of "positive versus zero growth" rise by 19.2 (29.4) percent by a one-standard-deviation increase of Cash flow for small (medium-large) enterprises, while the odds of "negative versus zero growth" fall by 21.4 (22.3) percent. Finally, the relative risk ratio for Leverage greater than one suggests that, for small firms, access to external financial resources is especially important for pursuing positive employment-growth projects.

\subsection{The occupational-intensity choice}

Maintaining long-lasting ties with a main bank seems to adversely affect the decision to increase the employment-size by small enterprises, while it seems to support the decision to postpone the firing of workers by medium-large enterprises. But do close bank ties influence the decision on the number of workers to hire or fire, and if so, in what way? In other words, how do enduring credit relationships influence the firms' occupational-intensity choice?

Clearly, the simple strategy of splitting the Growth variable and estimating OLS models for the two sub-samples of positively and negatively growing firms would produce biased results if, as is reasonable to assume, the inclusion in the sub-samples is correlated with unobservable explanatory variables that affect the intensity of positive and negative growth (Heckman 1979). To overcome this difficulty, we build two distinct sample selection models where the equation of interest is the intensity of positive and negative employment-growth and the selection equations are the binary-choice models for the probability of firms increasing or decreasing occupation. Therefore:

$$
\begin{array}{rlr}
\text { Growth }_{1 i t} & =\left\{\begin{array}{ll}
\text { Growth }_{i t} & \text { if } Z_{1 i t}=1 \\
\text { missing } & \text { if } Z_{1 i t}=0
\end{array} ;\right. & \operatorname{Prob}\left(Z_{1 i t}=1 \mid \mathbf{x}_{1 i t}\right)=\Phi\left(\mathbf{x}_{1 i t}^{\prime} \boldsymbol{\delta}_{1}\right)
\end{array}
$$

where $\Phi(\cdot)$ is the cumulative normal probability function and: 


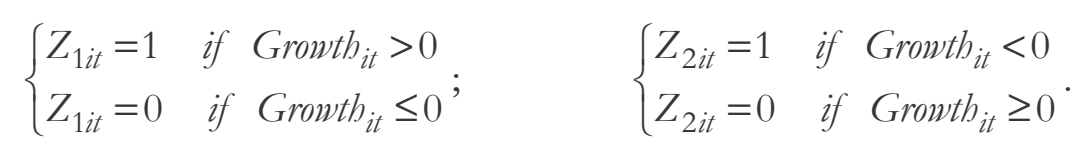

Models (4a) and (4b) are estimated with Heckman's two-step procedure. We first estimate the selection equation as a probit on the full sample of small and medium-large enterprises, respectively. Then we estimate the equation of interests by running OLS on the non-missing values of Growth 1 it and Growth $_{2 i t}$, adding as explanatory the estimated Heckman lambdas, $\hat{\lambda}_{1 i t}=\phi\left(\mathbf{x}_{1 i t}^{\prime} \hat{\boldsymbol{\delta}}_{1}\right) / \Phi\left(\mathbf{x}_{1 i t}^{\prime} \hat{\boldsymbol{\delta}}_{1}\right)$ and $\hat{\lambda}_{2 i t}=\phi\left(\mathbf{x}_{2 i t}^{\prime} \hat{\boldsymbol{\delta}}_{2}\right) / \Phi\left(\mathbf{x}_{2 i t}^{\prime} \hat{\boldsymbol{\delta}}_{2}\right)$, to allow for the possible correlation between the error terms in the growth and selection equations.

Table 7 displays results for the two-step Heckit estimator. As specific regressors for the selection models, we use three dummy variables: (i) Roa which is equal to 1 for firms with a Return on asset ratio greater than zero and 0 otherwise; (ii) Default risk which is 1 for firms whose one-year probability of default is greater than 0.053 (the median value for the whole sample) ${ }^{27}$; (iii) Credit rationing equal to 1 if the firm reports it sought more credit at the interest rate agreed with the bank and 0 otherwise. The idea is that profitability, riskiness - when greater (lower) than a certain threshold - and creditconstraints should affect the direction of firms' growth more than its intensity ${ }^{28}$.

\section{[nsert Table 7]}

Consistent with multinomial logit findings, the estimations for the selection mechanisms clearly indicate that the longer the credit relationship with the main bank, the lower the probability that a small firm falls within the sample of firms that increase their employment-size (the coefficient for Main-bank relationship length is significantly negative at the 1 percent level) and that a large firm dismisses workers (even though in this case the estimated coefficient is significant only at the 10 percent level). By

\footnotetext{
${ }^{27}$ The one-year probability of default is drawn from the RiskCalc ${ }^{\mathrm{TM}}$ Italy model developed by Moody's KMV (Dwyer et al. 2004). The RiskCalc ${ }^{\mathrm{TM}}$ model for one-year risk of default combines firm's financial statement ratios concerning profitability, leverage, debt coverage, growth, liquidity, activity ratios and size. We thank Toni Riti of Unicredit for kindly providing us with Default reisk variable.

${ }^{28}$ It is worth noting that when we include Roa, Default risk and Credit rationing in the least squares regression, they are not significantly associated either with Growth ${ }_{1 i t}$ or with Growth $_{2 i t}$.
} 
contrast, the effects of long-lasting bank ties on the likelihood of small firms decreasing and mediumlarge firms increasing their occupation are no different from zero.

Moving on to the occupational-intensity choice, first of all it is worth noting that the inverse Mill's ratios are no significantly different from zero, suggesting that there may not be any correlation between the unobserved determinants of the propensity to grow, positively or negatively $\left(Z_{1 i t}\right.$ and $\left.Z_{2 i t}\right)$, and unobserved determinants of Growth ${ }_{1 i t}$ and Growth ${ }_{2 i t}$. Second, the coefficient for Main-bank relationship length is statistically significant only in the case of the positive growth of small firms and with a negative sign. For the negative growth of medium-large firms the effect of long-lasting bank ties with the main bank is positive, consistent with the LDEcB mark II hypothesis, but the p-value is at the 19 percent level of significance.

\section{Conclusions}

Bank-firm relationships undergo a fundamental transformation during their lifetime. Both banks and firms invest resources in relation-specific activities that boost the value of the relationship, but that also generate a two-sided dependency locking the parties into the relationship. If one reasonably assumes that information problems are more acute for small firms and that banks have more resources at stake with large firms and are more concerned about their failure, then it can be safely conjectured that banks capture small firms, while they are captured by large firms.

In this paper, we provided empirical support for this conjecture by looking at the effects that longlasting ties with the main bank have on firms' employment and asset growth. Our main findings can be summarized as follows. First of all, small firms maintaining a stable credit relationship with a main bank grow relatively less, on average, than bank-independent firms. In particular, small healthy firms seem to be captured by long-lasting main-banks who are keen to curb the growth intentions of small firms in order not to lose market power over them. By contrast, maintaining stable relationships with a main bank does not allow troubled, small firms to contain their decline in employment and asset size. 
With regard to medium-large firms, regression results are almost the opposite. On average, longlasting bank ties have no significant impact on growth performance of medium-large firms. However, the probability that medium-large firms, when in trouble, decrease their size permanently by dismissing part of their workforce is significantly lower if they have stable credit ties with a main bank, which appears to be captured in the relationship. 


\section{References}

Agarwal R., Elston J.A. (2001), "Bank-Firm Relationships, Financing and Firm Performance in Germany", Economic Letters, 72, pp. 225-232.

Alchian A.A. (1987), "Concluding Remarks", Journal of Institutional and Theoretical Economics, 143, pp. 232 34

Alessandrini P., Presbitero A.F., Zazzaro A. (2009a), “Banks, Distances and Firms' Financing Constraints", Review of Finance, Advance Access published online on April 24, 2008.

Alessandrini P., Presbitero A.F., Zazzaro A. (2009b), Geographical Organization of Banking Systems and Innovation Diffusion, in P. Alessandrini, M. Fratianni, A. Zazzaro, (eds), The Changing Geography of Banking and Finance, New York: Springer.

Andrews D.W.K., Stock J.H. (2005), "Inference with Weak Instruments", Cowles Foundation Discussion Paper No. 1530.

Angelini P., Di Salvo R., Ferri G. (1998), “Availability and Cost of Credit for Small Business: Customer Relationships and Credit Cooperatives", Journal of Banking and Finance, 22, pp. 925-954.

Becchetti L., Trovato G. (2002), "The Determinants of Growth for Small and Medium Sized Firms. The Role of the Availability of External Finance", Small Business Economics, 19, pp. 291-306.

Berger A.N., Udell G. (1995), "Relationship Lending and Lines of Credit in Small Firm Finance", Journal of Business, 3, pp. 351-381.

Bharath S., Dahiya S., Saunders A., Srinivasan A. (2007), "So What do I Get? The Bank's View of Lending Relationships", Journal of Financial Economics, 85, pp. 368-419.

Blackwell D.W., Winters D.B. (1997), "Banking Relationships and the Effect of Monitoring on Loan Pricing", The Journal of Financial Research, 20(2), pp. 275-289.

Boot A. (2000), "Relationship Banking: What Do We Know?", Journal of Financial Intermediation, 9, pp. 7 25.

Boot A., Thakor A. (2000), “Can Relationship Banking Survive Competition?”, Journal of Finance, 55, pp. 679-713. 
Brick I.E., Palia D. (2007), "Evidence on the Jointness in the Terms of Relationship Lending”, Journal of Financial Intermediation, 16(3), pp. 452-476.

Brunner A., Krahnen J.P. (2008), "Multiple Lenders and Corporate Distress: Evidence on Debt Restructuring", Review of Economic Studies, 75(2), pp. 415-442.

Carpenter R., Petersen B. (2002), "Is the Growth of Small Firms Constrained by Internal Finance?”, Review of Economics and Statistics, 84, pp. 298-309.

Chakraborty A., Hu C.X. (2006), "Lending Relationships in Line-of-Credit and Nonline-of-Credit Loans: Evidence from Collateral Use in Small Business," Journal of Financial Intermediation, 15(1), pp. 86-107.

Chao J.C., Swanson N.R. (2005), “Consistent Estimation with a Large Number of Weak Instruments", Econometrica, 73, pp. 1673-1692.

Chirinko R., Elston J.A. (2006), "Finance, Control and Profitability: the Influence of German Banks", Journal of Economic Behaviour \& Organization, 59, pp. 69-88.

Cole R.A. (1998), “The Importance of Relationships to the Availability of Credit”, Journal of Banking and Finance, 22, pp. 227-251.

Degryse H., Ongena S. (2001), "Bank Relationships and Firm Profitability”, Financial Management, 30, pp. 9-34.

Degryse H., Van Cayseele P. (2000), "Relationship Lending within a Bank-Based System: Evidence from European Small Business Data”, Journal of Financial Intermediation, 9, pp. 90-109.

Dell'Ariccia G., Marquez R. (2004) "Information and bank credit allocation," Journal of Financial Economics, 72(1), pp. 185-214.

Dewatripont M., Maskin E. (1995), "Credit and Efficiency in Centralized and Decentralized Economies", Review of Economic Studies 62(4), pp. 541-555.

Dunne P., Hughes A. (1994), “Age, Size, Growth and Survival: UK Companies in the 1980s”, Journal of Industrial Economics, 42, pp. 115-140. 
Dunne T., Roberts M.J., Samuelson L. (1989), "The Growth and Failure of Manufacturing Plants", Quarterly Journal of Economics, 104, pp. 671-698.

Dwyer D.W., Kocagil A.E., Stein R.M. (2004), “The Moody’s KMV EDF RiskCalc v3.1 Model: Next Generation technology for Predicting Private Firm Risk, Moody’s KMV Company:USA.

Elsas R. (2005), "Empirical Determinants of Relationship Lending", Journal of Financial Intermediation, 14, pp. 32-57.

Elston J.A. (2002), “An Examination of the Relationship Between Firm Size, Growth, and Liquidity in the Neuer Market", Economic Research Center of the Deutsche Bundesbank Discussion Paper Series No. 15.

Evans D.S. (1987), “The Relationship between Firm Growth, Size and Age: Estimates for 100 Manufacturing Industries”, Journal of Industrial Economics, 35, pp. 567-581.

Fok R.C., Chang Y.C., Lee W.T. (2004), "Bank Relationships and Their Effects on Firm Performance around the Asian Financial Crisis: Evidence from Taiwan”, Financial Management, 33, pp. 89-112.

Greene W.H. (2003), Econometric Analysis, New York: New York University.

Guiso L., Sapienza P., Zingales L. (2003), “Does Local Financial Development Matter?” CRSP Working Paper No. 538.

Guiso L., Sapienza P., Zingales L. (2004), “Does Local Financial Development Matter?”, The Quarterly Journal of Economics, 119, pp. 929-969.

Hall B.H. (1987), "The Relationship between Firm Size and Firm Growth in the US. Manufacturing Sector", Journal of Industrial Economics, 35, pp. 583-606.

Harhoff D., Körting T. (1998), "Lending Relationships in Germany- Empirical Evidence from Survey Data“, Journal of Banking and Finance, 22, pp. 1317-1353.

Hauswald R., Marquez R. (2006), "Competition and Strategic Information Acquisition in Credit Markets”, Review of Financial Studies, 19, pp. 967-1000.

Heckman J. (1979) "Sample selection bias as a specification error”, Econometrica, 47, pp. 153-161. 
Herrera A.M., Minetti R. (2007), “Informed Finance and Technological Change: Evidence from Credit Relationships", Journal of Financial Economics, 83, pp. 223-269.

Hernandez G., Martinez P. (2006), "Banking Relationships: Effects on the Debt Terms for Small Spanish Firms", Journal of Small Business Management, 44, pp. 315-333.

Heshmati A. (2001), "On the Growth of Micro and Small Firms: Evidence from Sweden", Small Business Economics, 17, pp. 213-228.

Honjo Y., Harada N. (2006), "SME Policy, Financial Structure and Firm Growth: Evidence from Japan”, Small Business Economics, 27, pp. 289-300.

Hoshi T., Kashyap A., Scharfstein D. (1990), “The Role of Banks in Reducing Financial Distress in Japan”, NBER Working Paper no. 3435.

Houston J.F., James C.M. (2001), “Do Relationships Have Limits? Banking Relationships, Financial Constraints and Investment", Journal of Business, 74, pp. 347-374.

Ijiri Y., Simon H.A. (1977), Skew Distribution and the Size of Business Firms, Amsterdam: North-Holland..

Jensen M.C., Meckling W.H. (1976), “Theory of the Firm: Managerial Behavior, Agency Costs and Ownership Structure", Journal of Financial Economics, 3, pp. 305-60.

Johnson S.H., La Porta R., Lopez de Silanes F., Shleifer A. (2000), “Tunnelling”, NBER Working Paper no. W7523.

Jovanovic B. (1982), “Selection and Evolution of Industry”, Econometrica, 50, pp. 649-670.

Kawai M., Hashimoto J., Izumida S. (1996), "Japanese firms in financial distress and main banks: Analyses of interest-rate premia", Japan and the World Economy, 8, pp. 175-194.

Lang L., Ofek E., Stulz R.M. (1996), "Leverage, Investment and Firm Growth”, Journal of Financial Economics, 40, pp. 3-29.

Longhofer S.D., Santos J.A.C. (2000), "The Importance of Bank Seniority for Relationship Lending", Journal of Financial Intermediation, 9(1), pp. 57-89.

Miarka T. (1999), The recent economic role of bank-firm relationships in Japan, Wissenschaftszentrum Berlin. 
Mikusheva A., Poi B.P. (2006), “Tests and Confidence Sets with Correct Size When Instruments are Potentially Weak", The Stata Journal, 6(3), pp. 335-347.

Montoriol Garriga J. (2006), "The effect of relationship lending on firm performance”, Universitat Autònoma de Barcelona Documents de Treball No. 06/5.

Moreira M. (2003) “A Conditional Likelihood Ratio Test for Structural Models”, Econometrica, 71, pp. 1027-48.

Murray M.P. (2006), “Avoiding Invalid Instruments and Coping with Weak Instruments”, Journal of Economic Perspectives, 20(4), pp. 111-132.

Myers S., Majluf N. (1984), "Corporate Financing Decisions when Firms Have Investment Information that Investors Do Not", Journal of Financial Economics, 13, pp. 187-220.

Nakatani I. (1984), “The Role of Financial Corporate Grouping”, in M. Aoki (ed), Economic Analysis of the Japanese Firm, New York: North-Holland.

OECD (2004), Employment Outlook, Paris.

Ogawa K., Sterken E., Tokutsu I. (2007), “Why do Japanese Firms Prefer Multiple Bank Relationship? Some Evidence from Firm-Level Data”, Economic Systems, 31, pp. 49-70.

Oliveira B., Fortunato A. (2006), "Firm Growth and Liquidity Constraints: A Dynamic Analysis", Small Business Economics, 27, pp. 139-156.

Ono A., Uesugi I. (2005), The Role of Collateral and Personal Guarantees in Relationship Lending: Evidence from Japan's Small Business Loan Market. RIETI Discussion Paper Series 05-E-027.

Ongena S., Smith D. (2001), “The Duration of Bank Relationships”, Journal of Financial Economics, 61, pp. $449-475$.

Opler T., Titman S. (1994), "Financial Distress and Corporate Performance", Journal of Finance, 49, pp. 1015-1040.

Peek J., Rosengren E.S. (2005), "Unnatural Selection: Perverse Incentives and the Misallocation of Credit in Japan," American Economic Review, 95(4), pp. 1144-1166. 
Petersen M.A., Rajan R.G. (1994), "The Benefits of Lending Relationships: Evidence from Small Business Data”, Journal of Finance, 49, pp. 3-37.

Petersen M.A., Rajan R.G. (1995), "The Effect of Credit Market Competition on Lending Relationships", Quarterly Journal of Economics, 110, pp. 406-443.

Presbitero A.F., Zazzaro A. (2009), "Competition and Relationship Lending: Friends or Foes?" Mo.Fi.R. Working Paper no. 8/09.

Rajan R.G. (1992), "Insiders and Outsiders: The Choice between Informed and Arm's-Length Debt”, Journal of Finance, 47, pp. 1367-1400.

Rajan R.G., Servaes H., Zingales L. (2000), "The Cost of Diversity: The Diversification Discount and Inefficient Investment," Journal of Finance, 55(1), pp. 35-80.

Ross S. (1977), “The Determination of Financial Structure: The Incentive-Signaling Approach”, Bell Journal of Economics, 8, pp. 23-40.

Sharpe S.A. (1990), “Asymmetric Information, Bank Lending and Implicit Contracts: A Stylized Model of Customer Relationships", Journal of Finance, 45, pp. 1069-1087.

Sakai, K., Uesugi I., Watanabe, T. (2005), “Firm Age and the Evolution of Borrowing Costs: Evidence from Japanese Small Firms”, RIETI Discussion Paper Series 05-E-026.

Stock J.H., Yogo M. (2005), Testing for Weak Instruments in Linear IV Regression, in D.W.K. Andrews, J.H. Stock, (eds), Identification and Inference for Econometric Models: Essays in Honor of Thomas Rothenberg, Cambridge: Cambridge University Press, pp. 80-108.

Stulz R.M. (1990), "Managerial Discretion and Optimal Financing Policies", Journal of Financial Economics, 26, pp. 3-27.

Sutton J. (1997), “Gibrat's Legacy”, Journal of Economic Literature, 35(1), pp. 40-59.

Weinstein D., Yafeh Y. (1998), "On the Costs of a Bank-Centered Financial System: Evidence from the Changing Main Bank Relations in Japan”, Journal of Finance, 53, pp. 635-672.

Williamson O. (1976), "Franchise Bidding for Natural Monopolies - In General and With Respect to CATV”, Bell Journal of Economics, 7, pp. 73-104. 
Williamson O. (1976), "Franchise Bidding for Natural Monopolies - In General and With Respect to CATV”, Bell Journal of Economics, 7, 73-104.

Williamson O. (1985), The Economic Institutions of Capitalism, New York: Free Press.

Yafeh Y., Yosha O. (2003), "Large Shareholders and Banks: Who Monitors and How?" Economic Journal, 113, pp.128-146. 
Table 1. Variables and sources

\begin{tabular}{|c|c|c|}
\hline Variables & Definitions & Sources \\
\hline Growth & $\begin{array}{l}\text { Employment or assets average annual rate of growth computed as the difference between the } \\
\text { logarithms of the respective levels over the length of the period. }\end{array}$ & Unicredit-Capitalia Surveys \\
\hline Duration & $\begin{array}{l}\text { Credit length minus } 3 \text { if credit length is greater than } 3 \text { and } 0 \text { if credit length is less than or equal } \\
\text { to } 3 .\end{array}$ & Unicredit-Capitalia Surveys \\
\hline Main-bank relationship length & Natural logarithm of (1 + Duration) divided by 10 . & Unicredit-Capitalia Surveys \\
\hline Size & $\begin{array}{l}\text { Natural logarithm of the number of employees or total assets (measured in euro at constant } \\
\text { prices of 1995). }\end{array}$ & Unicredit-Capitalia Surveys \\
\hline Age & $\begin{array}{l}\text { Natural logarithm of } 1 \text { plus the age of the firm computed as the year of the survey minus the } \\
\text { year of inception. }\end{array}$ & Unicredit-Capitalia Surveys \\
\hline Cash flow & Cash flow over total assets. Cash flow computed as ordinary profits plus depreciation. & Unicredit-Capitalia Surveys \\
\hline Leverage & Leverage ratio computed as debt over total assets. & Unicredit-Capitalia Surveys \\
\hline Export & Dummy that takes the value of 1 if firm exports and 0 otherwise. & Unicredit-Capitalia Surveys \\
\hline Group & Dummy that takes the value of 1 if firm belongs to a group and 0 otherwise. & Unicredit-Capitalia Surveys \\
\hline$R \& D$ & Dummy that takes the value of 1 if firm had R\&D expenditures and 0 otherwise. & Unicredit-Capitalia Surveys \\
\hline$M \& A$ & $\begin{array}{l}\text { Dummy that takes the value of } 1 \text { if the firm took over or merged with other firms in the } 3 \text {-year } \\
\text { period and } 0 \text { otherwise. }\end{array}$ & Unicredit-Capitalia Surveys \\
\hline HHI & $\begin{array}{l}\text { Herfindahl-Hirschman Index calculated, by province, on the number of branches (divided by } \\
\text { 1000). }\end{array}$ & Bank of Italy \\
\hline Local bank & $\begin{array}{l}\text { Dummy that takes the value of } 1 \text { if the firm and its main bank are headquartered in the same } \\
\text { province and } 0 \text { otherwise. }\end{array}$ & Unicredit-Capitalia Surveys \\
\hline Branches & $\begin{array}{l}\text { Number of banks' branches in the province where the firm is headquartered, per } 10000 \\
\text { inhabitants, in } 1936 \text {. }\end{array}$ & Bank of Italy \\
\hline Cooperative banks & $\begin{array}{l}\text { Share of branches held by credit cooperative banks in the province where the firm is } \\
\text { headquartered, in } 1936 \text {. }\end{array}$ & Bank of Italy \\
\hline Saving banks & $\begin{array}{l}\text { Share of branches held by saving banks in the province where the firm is headquartered, in } \\
\text { 1936. }\end{array}$ & Bank of Italy \\
\hline New branch entrants & $\begin{array}{l}\text { Average number of branches created by entrants in the province where the firm is } \\
\text { headquartered in 1991-1998 (divided by 1000). }\end{array}$ & Bank of Italy \\
\hline New branch incumbents & $\begin{array}{l}\text { Average number of branches created by incumbents in the province where the firm is } \\
\text { headquartered in 1991-1998 (divided by 1000). }\end{array}$ & Bank of Italy \\
\hline Roa & $\begin{array}{l}\text { Dummy that takes the value of } 1 \text { for firms with a return on assets ratio greater than } 0 \text {, and } 0 \\
\text { otherwise. }\end{array}$ & Unicredit-Capitalia Surveys \\
\hline Default risk & $\begin{array}{l}\text { Dummy that takes the value of } 1 \text { for firms whose one-year probability of default is greater than } \\
0.053 \text { (the median value for the whole sample) an } 0 \text { otherwise. }\end{array}$ & Unicredit-Capitalia Surveys \\
\hline Credit rationing & $\begin{array}{l}\text { Dummy that takes the value of } 1 \text { if the firm reports it has sought more credit at the interest rate } \\
\text { agreed with the bank and } 0 \text { otherwise. }\end{array}$ & Unicredit-Capitalia Surveys \\
\hline
\end{tabular}


Table 2. Summary statistics by firm size

\begin{tabular}{|c|c|c|c|c|c|c|}
\hline \multirow[b]{2}{*}{ Variables } & \multicolumn{3}{|c|}{$\begin{array}{c}\text { Small business } \\
(<50 \text { employees } \& \text { total assets } \leq € 5 \\
\text { million })\end{array}$} & \multicolumn{3}{|c|}{$\begin{array}{c}\text { Medium-large business } \\
(\geq 50 \text { employees or total assets }>€ 5 \\
\text { million })\end{array}$} \\
\hline & Obs. & Mean & Std. Dev. & Obs. & Mean & Std. Dev. \\
\hline Growth (employment) & 2725 & 0.012 & 0.078 & 5141 & 0.019 & 0.102 \\
\hline Growth (assets) & 2715 & 0.044 & 0.135 & 3366 & 0.031 & 0.123 \\
\hline Duration & 2547 & 13.327 & 10.488 & 4640 & 14.325 & 12.152 \\
\hline Main-bank relationship length & 2547 & 0.235 & 0.088 & 4640 & 0.236 & 0.097 \\
\hline Size (employment in levels) & 2725 & 22.050 & 8.624 & 5143 & 149.316 & 481.787 \\
\hline Size (employment in logarithms) & 2725 & 3.023 & 0.370 & 5143 & 4.067 & 1.164 \\
\hline Size (assets in levels) & 2725 & 1493997 & 948597 & 3418 & 36700000 & 14300000 \\
\hline Size (assets in logarithms) & 2725 & 14.019 & 0.644 & 3418 & 16.304 & 1.190 \\
\hline Age (in levels) & 2692 & 23.569 & 15.826 & 4976 & 28.173 & 19.925 \\
\hline Age (in logarithms) & 2692 & 2.979 & 0.611 & 4976 & 3.118 & 0.687 \\
\hline Cash flow & 2725 & 0.065 & 0.056 & 3418 & 0.067 & 0.053 \\
\hline Leverage & 2725 & 0.681 & 0.180 & 3418 & 0.658 & 0.176 \\
\hline Export & 2710 & 0.604 & 0.489 & 5110 & 0.765 & 0.424 \\
\hline Group & 2720 & 0.102 & 0.302 & 5158 & 0.329 & 0.470 \\
\hline$R \& D$ & 2696 & 0.298 & 0.458 & 5042 & 0.474 & 0.499 \\
\hline$M \& A$ & 2717 & 0.039 & 0.195 & 5149 & 0.133 & 0.340 \\
\hline$H H I$ & 2725 & 1.115 & 0.460 & 5167 & 1.109 & 0.496 \\
\hline Local bank & 2649 & 0.631 & 0.483 & 4875 & 0.593 & 0.491 \\
\hline Branches & 2725 & 2.043 & 0.798 & 5167 & 2.002 & 0.827 \\
\hline Cooperative banks & 2725 & 0.157 & 0.141 & 5167 & 0.160 & 0.136 \\
\hline Saving banks & 2725 & 0.208 & 0.134 & 5167 & 0.190 & 0.129 \\
\hline New branch entrants & 2725 & 0.008 & 0.007 & 5167 & 0.008 & 0.008 \\
\hline New branch incumbents & 2725 & 0.020 & 0.023 & 5167 & 0.023 & 0.025 \\
\hline Roa & 2435 & 0.870 & 0.336 & 4458 & 0.843 & 0.364 \\
\hline Default risk & 2429 & 0.503 & 0.500 & 4396 & 0.492 & 0.500 \\
\hline Credit rationing & 2684 & 0.186 & 0.389 & 4957 & 0.163 & 0.370 \\
\hline
\end{tabular}

Obs. =Observations, Std. Dev. = standard deviation.

Note: Assets are measured in euro. In this table the descriptive statistics are divided by 1000 . 
Table 3. Determinants of firms' growth. OLS results.

The table reports OLS regression coefficients and associated p-values. The dependent variable in columns (1), (3), (5), (7), (9) and (11) is the employment percentage rate of growth computed as the difference between the logarithms of the respective levels over the length of the period. The dependent variable in columns (2), (4), (6), (8), (10) and (12) is the assets percentage rate of growth computed as the difference between the logarithms of the respective levels over the length of the period. We measure relationship length with the main bank as the logarithm of 1 plus the number of years with the main bank minus 3 (divided by 10). Size is the logarithm of the number of employees at the beginning of the period. Age is the logarithm of the number of years since the inception of the firm. Cash flow is the ratio of cash flow to total assets. Leverage is the ratio of debt to total assets. The $(0,1)$ notation means the variable is a dummy taking the value of 1 if the firm presents the specified characteristic and 0 otherwise. In order to check for robustness in columns $(3)$, (4), (7), (8), (11) and (12) three additional control variables are added to the basic regression: $M \& A$, HHI and Local bank, controlling for external growth through mergers and acquisitions, the concentration of the local credit market and the localism of the main bank respectively. All regressions include industrial, geographic and time dummies. $* * *, * *$ and $*$ indicate statistically significant at the $1 \%, 5 \%$ and $10 \%$ level, respectively. The table also reports, as a goodness-of-fit test, the p-values of the F-statistic for the Wald test of joint significance of regressors.

\begin{tabular}{|c|c|c|c|c|c|c|c|c|c|c|c|c|}
\hline & \multicolumn{4}{|c|}{ Panel A: whole sample } & \multicolumn{4}{|c|}{ Panel B: small business } & \multicolumn{4}{|c|}{ Panel C: medium-large business } \\
\hline & $\begin{array}{c}\text { Empl. } \\
(1)\end{array}$ & $\begin{array}{c}\text { Assets } \\
(2)\end{array}$ & $\begin{array}{c}\text { Empl. } \\
(3)\end{array}$ & $\begin{array}{c}\text { Assets } \\
\text { (4) }\end{array}$ & $\begin{array}{c}\text { Empl. } \\
\text { (5) }\end{array}$ & $\begin{array}{c}\text { Assets } \\
(6)\end{array}$ & $\begin{array}{c}\text { Empl. } \\
(7)\end{array}$ & $\begin{array}{c}\text { Assets } \\
(8)\end{array}$ & $\begin{array}{c}\text { Empl. } \\
(9)\end{array}$ & $\begin{array}{c}\text { Assets } \\
(10)\end{array}$ & $\begin{array}{c}\text { Empl. } \\
(11)\end{array}$ & $\begin{array}{c}\text { Assets } \\
(12)\end{array}$ \\
\hline \multicolumn{13}{|l|}{ Relationship-banking } \\
\hline Main-bank relationship length & $\begin{array}{l}-0.007 \\
(0.598)\end{array}$ & $\begin{array}{l}-0.024 \\
(0.258)\end{array}$ & $\begin{array}{l}-0.002 \\
(0.899)\end{array}$ & $\begin{array}{l}-0.022 \\
(0.300)\end{array}$ & $\begin{array}{c}-0.044 * * \\
(0.041)\end{array}$ & $\begin{array}{c}-0.079 * * \\
(0.037)\end{array}$ & $\begin{array}{c}-0.044 * * \\
(0.038)\end{array}$ & $\begin{array}{c}-0.085^{* *} \\
(0.025)\end{array}$ & $\begin{array}{c}0.014 \\
(0.385)\end{array}$ & $\begin{array}{c}0.010 \\
(0.697)\end{array}$ & $\begin{array}{c}0.022 \\
(0.190)\end{array}$ & $\begin{array}{c}0.017 \\
(0.497)\end{array}$ \\
\hline \multicolumn{13}{|l|}{$\underline{\text { Controls }}$} \\
\hline Size & $\begin{array}{c}-0.009 * * * \\
(0.000)\end{array}$ & $\begin{array}{c}-0.011^{* * *} \\
(0.000)\end{array}$ & $\begin{array}{c}-0.011 * * * \\
(0.000)\end{array}$ & $\begin{array}{c}-0.012^{* * *} \\
(0.000)\end{array}$ & $\begin{array}{c}-0.036^{* * *} \\
(0.000)\end{array}$ & $\begin{array}{c}-0.029 * * * \\
(0.000)\end{array}$ & $\begin{array}{c}-0.036^{* * *} \\
(0.000)\end{array}$ & $\begin{array}{c}-0.031 * * * \\
(0.000)\end{array}$ & $\begin{array}{c}-0.014 * * * \\
(0.000)\end{array}$ & $\begin{array}{c}-0.019 * * * \\
(0.000)\end{array}$ & $\begin{array}{c}-0.015^{* * *} \\
(0.000)\end{array}$ & $\begin{array}{c}-0.020 * * * \\
(0.000)\end{array}$ \\
\hline Age & $\begin{array}{c}-0.008^{* * *} \\
(0.000)\end{array}$ & $\begin{array}{c}-0.011^{* * *} * \\
(0.002)\end{array}$ & $\begin{array}{c}-0.008^{* * *} \\
(0.000)\end{array}$ & $\begin{array}{c}-0.012^{* * *} \\
(0.001)\end{array}$ & $\begin{array}{c}-0.007 * * \\
(0.028)\end{array}$ & $\begin{array}{c}-0.019 * * * \\
(0.001)\end{array}$ & $\begin{array}{c}-0.006^{* *} \\
(0.049)\end{array}$ & $\begin{array}{c}-0.019 * * * \\
(0.001)\end{array}$ & $\begin{array}{c}-0.008^{* * * *} \\
(0.003)\end{array}$ & $\begin{array}{l}-0.006 \\
(0.180)\end{array}$ & $\begin{array}{c}-0.008^{* * *} \\
(0.002)\end{array}$ & $\begin{array}{c}-0.007 * \\
(0.075)\end{array}$ \\
\hline Cash flow & $\begin{array}{c}0.237 * * * \\
(0.000)\end{array}$ & $\begin{array}{c}0.282 * * * \\
(0.000)\end{array}$ & $\begin{array}{c}0.238^{* * *} \\
(0.000)\end{array}$ & $\begin{array}{c}0.282 * * * \\
(0.000)\end{array}$ & $\begin{array}{c}0.188^{* * *} \\
(0.000)\end{array}$ & $\begin{array}{c}0.190^{* * * *} \\
(0.000)\end{array}$ & $\begin{array}{c}0.191 * * * \\
(0.000)\end{array}$ & $\begin{array}{c}0.183^{* * *} \\
(0.001)\end{array}$ & $\begin{array}{c}0.289 * * * \\
(0.000)\end{array}$ & $\begin{array}{c}0.356^{* * *} \\
(0.000)\end{array}$ & $\begin{array}{c}0.287 * * * \\
(0.000)\end{array}$ & $\begin{array}{c}0.362^{* * *} \\
(0.000)\end{array}$ \\
\hline Leverage & $\begin{array}{c}0.052 * * * \\
(0.000)\end{array}$ & $\begin{array}{c}0.027 * * \\
(0.015)\end{array}$ & $\begin{array}{c}0.051 * * * \\
(0.000)\end{array}$ & $\begin{array}{c}0.026^{* *} \\
(0.021)\end{array}$ & $\begin{array}{c}0.053^{* * *} * \\
(0.000)\end{array}$ & $\begin{array}{c}0.019 \\
(0.259)\end{array}$ & $\begin{array}{c}0.054 * * * \\
(0.000)\end{array}$ & $\begin{array}{c}0.015 \\
(0.391)\end{array}$ & $\begin{array}{c}0.046 * * * \\
(0.000)\end{array}$ & $\begin{array}{c}0.032 * * \\
(0.033)\end{array}$ & $\begin{array}{c}0.043 * * * \\
(0.000)\end{array}$ & $\begin{array}{c}0.033 * * \\
(0.031)\end{array}$ \\
\hline Export $(0,1)$ & $\begin{array}{c}0.009 * * * \\
(0.001)\end{array}$ & $\begin{array}{c}0.021 * * * \\
(0.000)\end{array}$ & $\begin{array}{c}0.009^{* * *} * \\
(0.000)\end{array}$ & $\begin{array}{c}0.022^{* * *} \\
(0.000)\end{array}$ & $\begin{array}{c}0.007 * * \\
(0.042)\end{array}$ & $\begin{array}{c}0.020 * * * \\
(0.001)\end{array}$ & $\begin{array}{c}0.007 * * \\
(0.032)\end{array}$ & $\begin{array}{c}0.020 * * * \\
(0.001)\end{array}$ & $\begin{array}{l}0.007^{*} \\
(0.055)\end{array}$ & $\begin{array}{c}0.017 * * \\
(0.023)\end{array}$ & $\begin{array}{l}0.008^{*} \\
(0.051)\end{array}$ & $\begin{array}{c}0.018^{* *} \\
(0.012)\end{array}$ \\
\hline Group $(0,1)$ & $\begin{array}{c}0.011^{* * *} \\
(0.000)\end{array}$ & $\begin{array}{c}0.003 \\
(0.571)\end{array}$ & $\begin{array}{c}0.009^{* * *} \\
(0.003)\end{array}$ & $\begin{array}{c}0.001 \\
(0.890)\end{array}$ & $\begin{array}{c}0.010^{* *} \\
(0.045)\end{array}$ & $\begin{array}{c}0.010 \\
(0.338)\end{array}$ & $\begin{array}{c}0.010^{* *} \\
(0.043)\end{array}$ & $\begin{array}{c}0.007 \\
(0.505)\end{array}$ & $\begin{array}{c}0.009 * * \\
(0.017)\end{array}$ & $\begin{array}{c}0.002 \\
(0.647)\end{array}$ & $\begin{array}{c}0.006 \\
(0.107)\end{array}$ & $\begin{array}{l}0.001 \\
(0.876)\end{array}$ \\
\hline$R \& D(0,1)$ & $\begin{array}{c}0.009^{* * * *} \\
(0.000)\end{array}$ & $\begin{array}{c}0.017 * * * \\
(0.000)\end{array}$ & $\begin{array}{c}0.008^{* * * *} \\
(0.003)\end{array}$ & $\begin{array}{c}0.016^{* * *} \\
(0.000)\end{array}$ & $\begin{array}{c}0.012^{* * * *} \\
(0.001)\end{array}$ & $\begin{array}{c}0.022 * * * \\
(0.000)\end{array}$ & $\begin{array}{c}0.010^{* * *} \\
(0.007)\end{array}$ & $\begin{array}{c}0.022 * * * \\
(0.000)\end{array}$ & $\begin{array}{c}0.005 \\
(0.124)\end{array}$ & $\begin{array}{c}0.013^{* * * *} \\
(0.007)\end{array}$ & $\begin{array}{c}0.005 \\
(0.178)\end{array}$ & $\begin{array}{c}0.011 * * \\
(0.021)\end{array}$ \\
\hline$M \& A(0,1)$ & & & $\begin{array}{c}0.033^{* * *} \\
(0.000)\end{array}$ & $\begin{array}{c}0.032^{* * *} \\
(0.000)\end{array}$ & & & $\begin{array}{c}0.029 * * * \\
(0.008)\end{array}$ & $\begin{array}{c}0.052 * * * \\
(0.004)\end{array}$ & & & $\begin{array}{c}0.033 * * * \\
(0.000)\end{array}$ & $\begin{array}{c}0.026 * * * \\
(0.000)\end{array}$ \\
\hline HHI & & & 0.002 & 0.003 & & & 0.001 & 0.002 & & & 0.004 & 0.003 \\
\hline Local bank & & & $\begin{array}{l}(0.517) \\
-0.003\end{array}$ & $\begin{array}{c}(0.465) \\
0.001\end{array}$ & & & $(0.845)$ & $(0.692)$ & & & $(0.228)$ & $(0.494)$ \\
\hline & & & $(0.181)$ & $(0.747)$ & & & $(0.743)$ & $(0.735)$ & & & $(0.157)$ & $(0.919)$ \\
\hline$\overline{\text { Industry }} \mathbf{-}-\mathbf{-}-\mathbf{-}$ & $\begin{array}{c}-\overline{\text { Yes }} \\
(0.000)\end{array}$ & $\begin{array}{l}\underset{\text { Yes }}{-}- \\
(0.000)\end{array}$ & $\begin{array}{l}\text { Yes } \\
(0.000)\end{array}$ & $\begin{array}{l}\text { Yes } \\
(0.001)\end{array}$ & $\begin{array}{l}\overline{\text { Yes }} \\
(0.000)\end{array}$ & $\begin{array}{l}\overline{\text { Yes }} \\
(0.000)\end{array}$ & $\begin{array}{c}-\frac{-}{\text { Yes }}- \\
(0.000)\end{array}$ & $\begin{array}{l}\text { Yes } \\
(0.000)\end{array}$ & $\begin{array}{l}\overline{\text { Yes }} \\
(0.000)\end{array}$ & $\begin{array}{l}\overline{\text { Yes }} \\
(0.000)\end{array}$ & $\begin{array}{c}-\frac{-}{\text { Yes }} \\
(0.000)\end{array}$ & $\begin{array}{c}-\bar{Y} \text { Yes } \\
(0.000)\end{array}$ \\
\hline
\end{tabular}




\begin{tabular}{|c|c|c|c|c|c|c|c|c|c|c|c|c|}
\hline $\begin{array}{l}\text { Area } \\
\text { Year }\end{array}$ & $\begin{array}{c}\text { Yes } \\
(0.000) \\
\text { Yes } \\
(0.000) \\
\end{array}$ & $\begin{array}{c}\text { Yes } \\
(0.000) \\
\text { Yes } \\
(0.000)\end{array}$ & $\begin{array}{c}\text { Yes } \\
(0.000) \\
\text { Yes } \\
(0.000) \\
\end{array}$ & $\begin{array}{c}\text { Yes } \\
(0.000) \\
\text { Yes } \\
(0.000) \\
\end{array}$ & $\begin{array}{c}\text { Yes } \\
(0.001) \\
\text { Yes } \\
(0.000) \\
\end{array}$ & $\begin{array}{c}\text { Yes } \\
(0.016) \\
\text { Yes } \\
(0.088) \\
\end{array}$ & $\begin{array}{c}\text { Yes } \\
(0.002) \\
\text { Yes } \\
(0.000) \\
\end{array}$ & $\begin{array}{c}\text { Yes } \\
(0.016) \\
\text { Yes } \\
(0.142)\end{array}$ & $\begin{array}{c}\text { Yes } \\
(0.000) \\
\text { Yes } \\
(0.000) \\
\end{array}$ & $\begin{array}{c}\text { Yes } \\
(0.002) \\
\text { Yes } \\
(0.000) \\
\end{array}$ & $\begin{array}{c}\text { Yes } \\
(0.000) \\
\text { Yes } \\
(0.000)\end{array}$ & $\begin{array}{c}\text { Yes } \\
(0.003) \\
\text { Yes } \\
(0.000) \\
\end{array}$ \\
\hline $\begin{array}{l}\text { Observations } \\
\text { Wald test ( } \mathrm{p} \text {-value) }\end{array}$ & $\begin{array}{l}5440 \\
0.000\end{array}$ & $\begin{array}{l}5409 \\
0.000\end{array}$ & $\begin{array}{l}5360 \\
0.000\end{array}$ & $\begin{array}{l}5329 \\
0.000\end{array}$ & $\begin{array}{l}2478 \\
0.000\end{array}$ & $\begin{array}{l}2470 \\
0.000\end{array}$ & $\begin{array}{l}2441 \\
0.000\end{array}$ & $\begin{array}{l}2433 \\
0.000\end{array}$ & $\begin{array}{l}2962 \\
0.000\end{array}$ & $\begin{array}{l}2939 \\
0.000\end{array}$ & $\begin{array}{l}2919 \\
0.000\end{array}$ & $\begin{array}{l}2896 \\
0.000\end{array}$ \\
\hline
\end{tabular}


Table 4. Determinants of firms' growth. Instrumental variable results

The table reports regression coefficients and associated p-values after instrumenting relationship lending. The dependent variable in columns (1), (2), (5), (6), (9) and (10) is the employment percentage rate of growth computed as the difference between the logarithms of the respective levels over the length of the period. The dependent variable in columns (3), (4), (7), (8), (11) and (12) is the assets percentage rate of growth computed as the difference between the logarithms of the respective levels over the length of the period. We measure relationship length with the main bank as the logarithm of 1 plus the number of years with the main bank minus 3 (divided by 10 ). Size is the logarithm of the number of employees at the beginning of the period. Age is the logarithm of the number of years since the inception of the firm. Cash flow is the ratio of cash flow to total assets. Leverage is the ratio of debt to total assets. The $(0,1)$ notation means the variable is a dummy taking the value of 1 if the firm presents the specified characteristic and 0 otherwise.. To control for endogeneity of the length of the credit relationship Main-bank relationship length is instrumented by the control variables and 5 excluded instruments. Branches is the number of banks' branches in the province where the firm is headquartered, per 10000 inhabitants, in 1936. Cooperative banks and Saving banks are the shares of branches held by credit cooperative banks and saving banks respectively in the province where the firm is headquartered, in 1936. New branch entrant and New branch incumbent are, respectively, the average numbers of branches created by entrants and incumbents where the firm is headquartered in the province in 1991-1998 (divided by 1000). First-stage coefficients and p-values for the excluded instruments are reported. In order to account for weakness of excluded instruments, coefficients in columns (1), (3), (5), (7), (9) and (11) are estimated by two-stage least squares (TSLS), while coefficients in columns (2), (4), (6), (8), (10) and (12) are estimated by limited-information maximum likelihood (LIML). Moreover, p-values from the standard $t$-test and the conditional likelihood ratio (CLR) test are reported for Main-bank relationship length. All regressions include industrial, geographic and time dummies. $* * *, * *$ and $*$ indicate statistically significant at the $1 \%, 5 \%$ and $10 \%$ level, respectively. The table also reports, as goodness-of-fit tests, the $F$-statistic for the $F$-test that the excluded instruments are jointly insignificant and the $\mathrm{p}$-values of the $\chi^{2}$-statistics for the tests of endogeneity of regressors and for the Sargan overidentification test of all instruments and the p-value of the $F$ statistic of the Wald test of joint significance of regressors.

\begin{tabular}{|c|c|c|c|c|c|c|c|c|c|c|c|c|}
\hline & \multicolumn{4}{|c|}{ Panel A: whole sample } & \multicolumn{4}{|c|}{ Panel B: small business } & \multicolumn{4}{|c|}{ Panel C: medium-large business } \\
\hline & \multicolumn{2}{|c|}{ Employment } & \multicolumn{2}{|c|}{ Assets } & \multicolumn{2}{|c|}{ Employment } & \multicolumn{2}{|c|}{ Assets } & \multicolumn{2}{|c|}{ Employment } & \multicolumn{2}{|c|}{ Assets } \\
\hline & $\begin{array}{l}\text { TSLS } \\
(1)\end{array}$ & $\begin{array}{c}\text { LIML } \\
(2)\end{array}$ & $\begin{array}{c}\text { TSLS } \\
\text { (3) }\end{array}$ & $\begin{array}{c}\text { LIML } \\
(4)\end{array}$ & $\begin{array}{l}\text { TSLS } \\
(5)\end{array}$ & $\begin{array}{c}\text { LIML } \\
(6)\end{array}$ & $\begin{array}{c}\text { TSLS } \\
(7)\end{array}$ & $\begin{array}{c}\text { LIML } \\
(8)\end{array}$ & $\begin{array}{l}\text { TSLS } \\
(9)\end{array}$ & $\begin{array}{c}\text { LIML } \\
(10)\end{array}$ & $\begin{array}{c}\text { TSLS } \\
(11)\end{array}$ & $\begin{array}{c}\text { LIML } \\
\text { (12) }\end{array}$ \\
\hline Relationship-banking & & & & & & & & & & & & \\
\hline $\begin{array}{l}\text { Main-bank relationship length } \\
\text { CLR p-value }\end{array}$ & $\begin{array}{l}-0.002 \\
(0.994) \\
(0.976)\end{array}$ & $\begin{array}{l}0.004 \\
(0.993) \\
(0.976)\end{array}$ & $\begin{array}{c}0.578 \\
(0.239) \\
(0.132)\end{array}$ & $\begin{array}{c}1.206 \\
(0.148) \\
(0.132)\end{array}$ & $\begin{array}{c}-1.241 * * \\
(0.040) \\
(0.012)\end{array}$ & $\begin{array}{c}-1.325^{* *} \\
(0.040) \\
(0.012)\end{array}$ & $\begin{array}{l}-1.078 \\
(0.184) \\
(0.175)\end{array}$ & $\begin{array}{l}-1.923 \\
(0.161) \\
(0.175)\end{array}$ & $\begin{array}{c}0.473 \\
(0.196) \\
(0.171)\end{array}$ & $\begin{array}{l}0.793 \\
(0.151) \\
(0.171)\end{array}$ & $\begin{array}{c}1.227 *(*) \\
(0.059) \\
(0.038)\end{array}$ & $\begin{array}{c}1.361 *(*) \\
(0.057) \\
(0.038)\end{array}$ \\
\hline Controls & & & & & & & & & & & & \\
\hline $\begin{array}{l}\text { Size } \\
\text { Age }\end{array}$ & $\begin{array}{c}-0.009 * * * \\
(0.000) \\
-0.008 \\
(0.689)\end{array}$ & $\begin{array}{c}-0.009 * * * \\
(0.000) \\
-0.009 \\
(0.778)\end{array}$ & $\begin{array}{c}-0.009 * * * \\
(0.000) \\
-0.053 \\
(0.125)\end{array}$ & $\begin{array}{c}-0.007^{*} \\
(0.073) \\
-0.097^{*} \\
(0.098)\end{array}$ & $\begin{array}{c}-0.035^{* * *} \\
(0.000) \\
0.083^{*} \\
(0.071)\end{array}$ & $\begin{array}{c}-0.035^{* * *} \\
(0.000) \\
0.089^{*} \\
(0.069)\end{array}$ & $\begin{array}{c}-0.033^{* * *} \\
(0.000) \\
0.057 \\
(0.360)\end{array}$ & $\begin{array}{c}-0.036^{* * *} \\
(0.000) \\
0.121 \\
(0.247)\end{array}$ & $\begin{array}{c}-0.012^{* * *} \\
(0.000) \\
-0.038 \\
(0.115)\end{array}$ & $\begin{array}{c}-0.011 * * * \\
(0.000) \\
-0.059 \\
(0.105)\end{array}$ & $\begin{array}{c}-0.012^{* * *} \\
(0.010) \\
-0.085^{* *} \\
(0.047)\end{array}$ & $\begin{array}{c}-0.012 * * \\
(0.024) \\
-0.094 * * \\
(0.046)\end{array}$ \\
\hline Cash flow & $\begin{array}{c}0.237 * * * \\
(0.000)\end{array}$ & $\begin{array}{c}0.237^{* * *} \\
(0.000)\end{array}$ & $\begin{array}{c}0.284^{* * *} \\
(0.000)\end{array}$ & $\begin{array}{c}0.286^{* * *} \\
(0.000)\end{array}$ & $\begin{array}{c}0.181 * * * \\
(0.000)\end{array}$ & $\begin{array}{c}0.180^{* * *} \\
(0.000)\end{array}$ & $\begin{array}{c}0.183^{* * *} \\
(0.002)\end{array}$ & $\begin{array}{c}0.177 * * \\
(0.019)\end{array}$ & $\begin{array}{c}0.287 * * * \\
(0.000)\end{array}$ & $\begin{array}{c}0.285^{* * *} \\
(0.000)\end{array}$ & $\begin{array}{c}0.358^{* * *} \\
(0.000)\end{array}$ & $\begin{array}{c}0.358^{* * *} \\
(0.000)\end{array}$ \\
\hline Leverage & $\begin{array}{c}0.052 * * * \\
(0.000)\end{array}$ & $\begin{array}{c}0.052^{* * *} \\
(0.003)\end{array}$ & $\begin{array}{c}0.049 * * \\
(0.023)\end{array}$ & $\begin{array}{c}0.072^{* *} \\
(0.032)\end{array}$ & $\begin{array}{c}0.009 \\
(0.738)\end{array}$ & $\begin{array}{c}0.006 \\
(0.835)\end{array}$ & $\begin{array}{l}-0.017 \\
(0.626)\end{array}$ & $\begin{array}{l}-0.047 \\
(0.388)\end{array}$ & $\begin{array}{c}0.063^{* * *} \\
(0.000)\end{array}$ & $\begin{array}{c}0.075^{* * *} \\
(0.002)\end{array}$ & $\begin{array}{c}0.079 * * \\
(0.014)\end{array}$ & $\begin{array}{c}0.084 * * \\
(0.015)\end{array}$ \\
\hline Export $(0,1)$ & $\begin{array}{c}0.009 * * * \\
(0.003)\end{array}$ & $\begin{array}{c}0.009 * * * \\
(0.007)\end{array}$ & $\begin{array}{c}0.018^{* * *} \\
(0.001)\end{array}$ & $\begin{array}{c}0.015^{* *} \\
(0.026)\end{array}$ & $\begin{array}{c}0.006 \\
(0.291)\end{array}$ & $\begin{array}{c}0.005 \\
(0.315)\end{array}$ & $\begin{array}{c}0.020^{* * *} \\
(0.004)\end{array}$ & $\begin{array}{c}0.020 * * \\
(0.021)\end{array}$ & $\begin{array}{c}0.003 \\
(0.636)\end{array}$ & $\begin{array}{l}-0.001 \\
(0.965)\end{array}$ & $\begin{array}{c}0.004 \\
(0.690)\end{array}$ & $\begin{array}{c}0.003 \\
(0.798)\end{array}$ \\
\hline $\operatorname{Group}(0,1)$ & $\begin{array}{l}0.011 * \\
(0.067)\end{array}$ & $\begin{array}{c}0.011 \\
(0.189)\end{array}$ & $\begin{array}{c}0.014 \\
(0.181)\end{array}$ & $\begin{array}{c}0.025 \\
(0.123)\end{array}$ & $\begin{array}{l}-0.006 \\
(0.595)\end{array}$ & $\begin{array}{l}-0.007 \\
(0.547)\end{array}$ & $\begin{array}{l}-0.004 \\
(0.791)\end{array}$ & $\begin{array}{l}-0.015 \\
(0.493)\end{array}$ & $\begin{array}{c}0.019^{* *} \\
(0.032)\end{array}$ & $\begin{array}{l}0.026 * * \\
(0.044)\end{array}$ & $\begin{array}{l}0.027 * \\
(0.071)\end{array}$ & $\begin{array}{l}0.029^{*} \\
(0.067)\end{array}$ \\
\hline$R \& D(0,1)$ & $\begin{array}{c}0.009 * * * \\
(0.000)\end{array}$ & $\begin{array}{c}0.009 * * * \\
(0.001)\end{array}$ & $\begin{array}{c}0.019^{* * *} \\
(0.000)\end{array}$ & $\begin{array}{c}0.021^{* * *} \\
(0.000)\end{array}$ & $\begin{array}{c}0.013^{* *} \\
(0.013)\end{array}$ & $\begin{array}{c}0.013^{* *} \\
(0.016)\end{array}$ & $\begin{array}{c}0.024 * * * \\
(0.001)\end{array}$ & $\begin{array}{c}0.025^{* * *} \\
(0.006)\end{array}$ & $\begin{array}{l}0.008^{*} \\
(0.060)\end{array}$ & $\begin{array}{l}0.011 * \\
(0.064)\end{array}$ & $\begin{array}{c}0.021 * * * \\
(0.007)\end{array}$ & $\begin{array}{c}0.021^{* * *} \\
(0.008)\end{array}$ \\
\hline
\end{tabular}




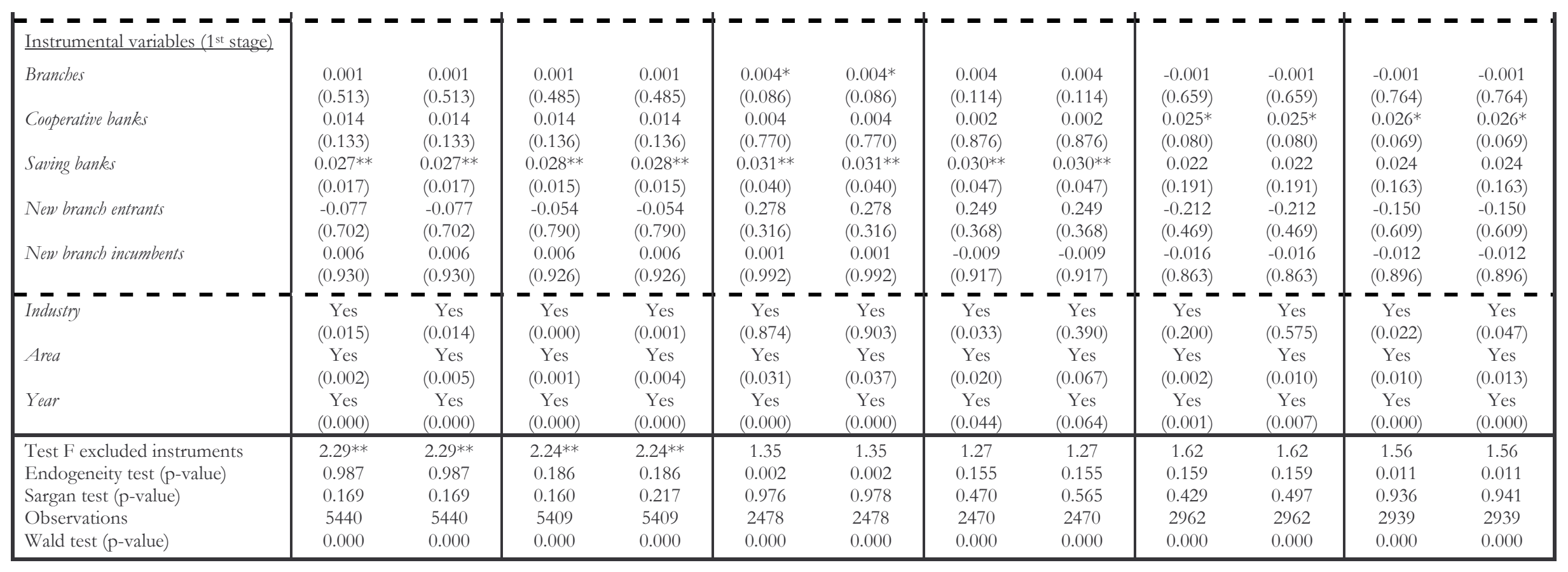


Table 5. Weak-instrument-robust inference on Main-bank relationship length.

The table reports the 95 percent confidence intervals and the p-value from the test on the coefficient of Main-bank relationship length based on the conditional likelihood ratio (CLR), the Anderson-Rubin and the Lagrange multiplier (score) test statistics. The CLR test developed by Moreira (2003) dominates the Anderson Rubin and the Lagrange multiplier (score) tests and its $\mathrm{p}$-value is also reported in table 4 together with the p-value from the standard $t$-test.

\begin{tabular}{|l|c|c|c|c|c|c|}
\hline & \multicolumn{2}{|c|}{ Panel A: whole sample } & \multicolumn{2}{c|}{ Panel B: small business } & \multicolumn{2}{c|}{$\begin{array}{c}\text { Panel C: medium-large } \\
\text { business }\end{array}$} \\
& Employment & Assets & Employment & Assets & Employment & Assets \\
\hline Conditional LR & {$[-\infty,+\infty]$} & {$[-\infty,+\infty]$} & {$[-22.011,-0.329]$} & {$[-\infty,+\infty]$} & {$[-\infty,+\infty]$} & {$[0.095,23.207]$} \\
CLR p-value & $(0.976)$ & $(0.132)$ & $(0.012)^{* *}$ & $(0.175)$ & $(0.171)$ & $(0.038)^{* *}$ \\
\hline Anderson-Rubin & {$[-3.355,3.638]$} & {$[-0.334,91.374]$} & {$[-\infty,+\infty]$} & {$[-\infty,+\infty]$} & {$[-\infty,+\infty]$} & {$[-\infty,+\infty]$} \\
ARp-value & $(0.271)$ & $(0.104)$ & $(0.049)^{* *}$ & $(0.228)$ & $(0.238)$ & $(0.159)$ \\
\hline Score $(\mathrm{LM})$ & {$[-\infty,+\infty]$} & {$[-\infty,+\infty]$} & {$[-6.559,0.933]$} & {$[-\infty,+\infty]$} & {$[-\infty,+\infty]$} & {$[-1.785,6.330]$} \\
\hline LM p-value & $(0.995)$ & $(0.193)$ & $(0.002)^{* * *}$ & $(0.150)$ & $(0.156)$ & $(0.011)^{* *}$ \\
\hline
\end{tabular}



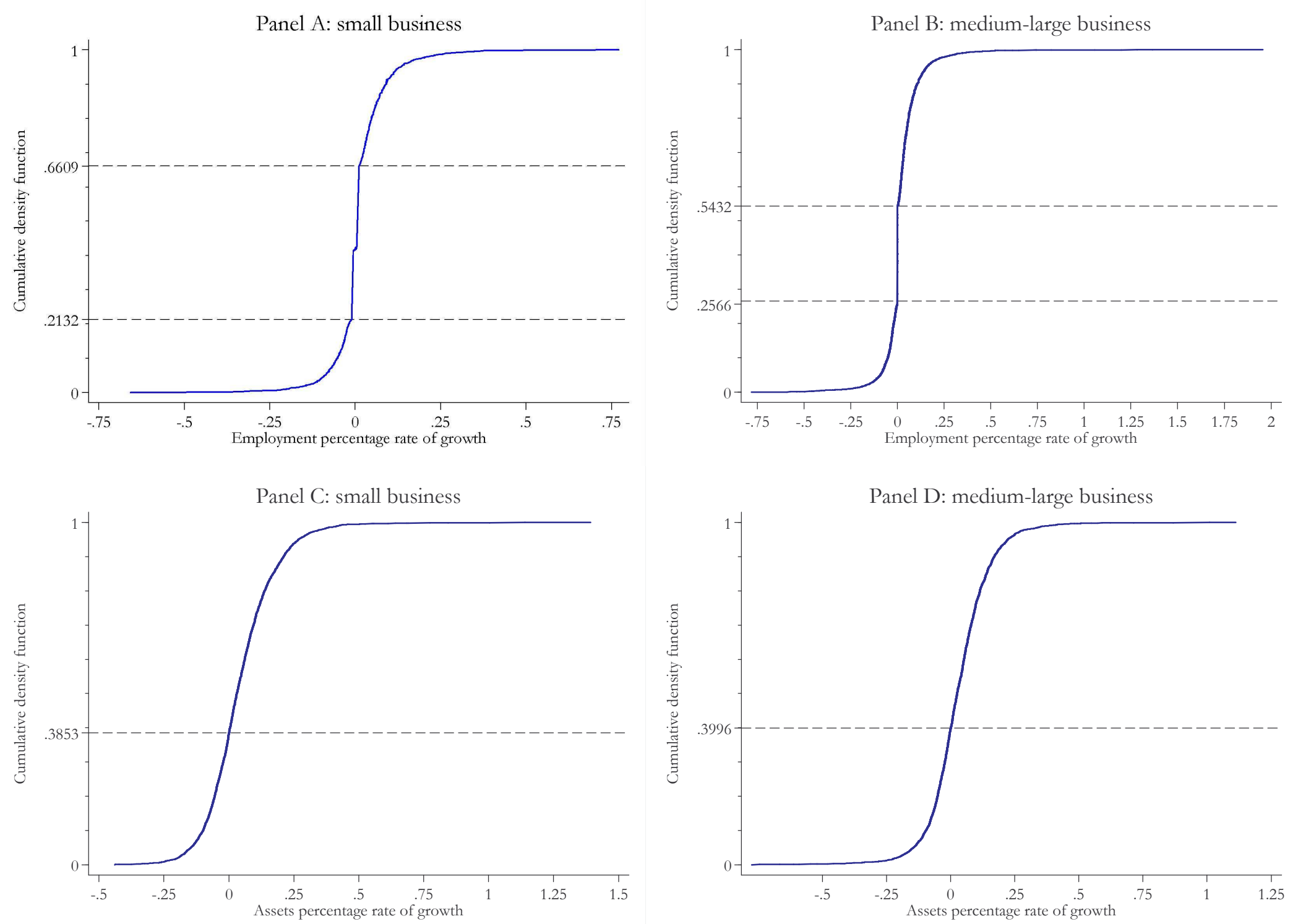

Figure 1. Employment- and asset-growth rate, cumulative density function 

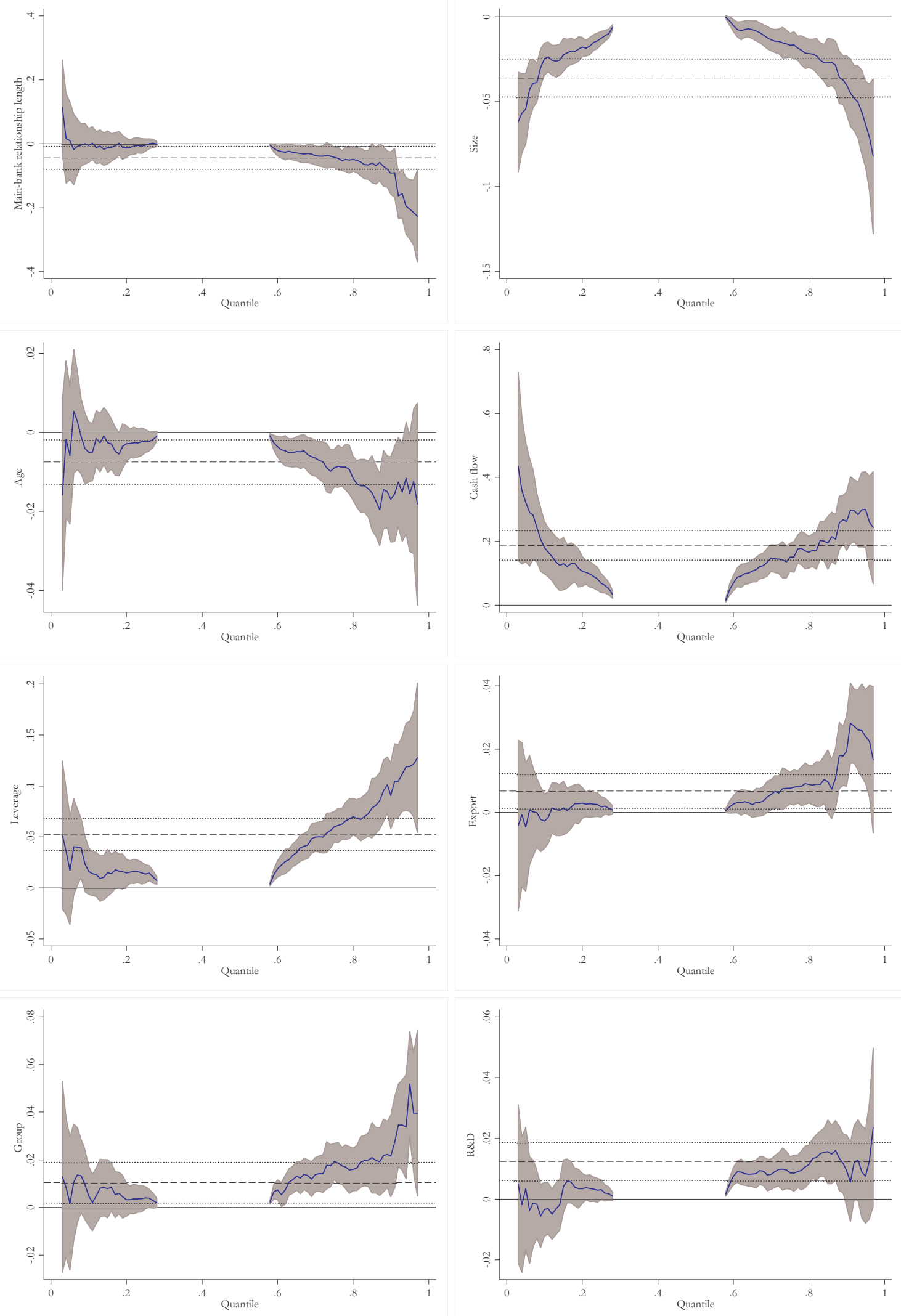

Figure 2A. Small business employment growth. Quantile regression results. 

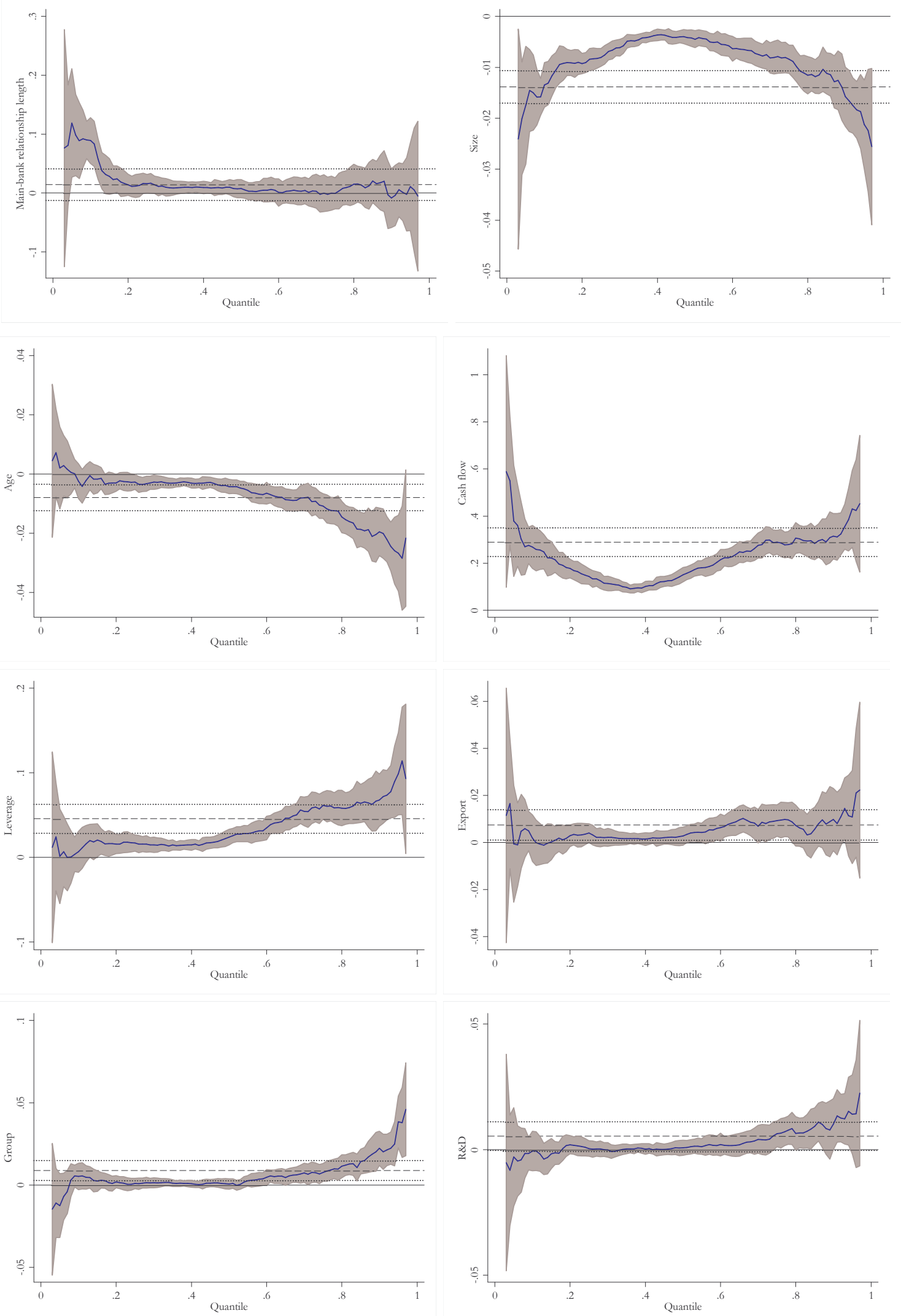

Figure 2B. Medium-large business employment growth. Quantile regression results. 

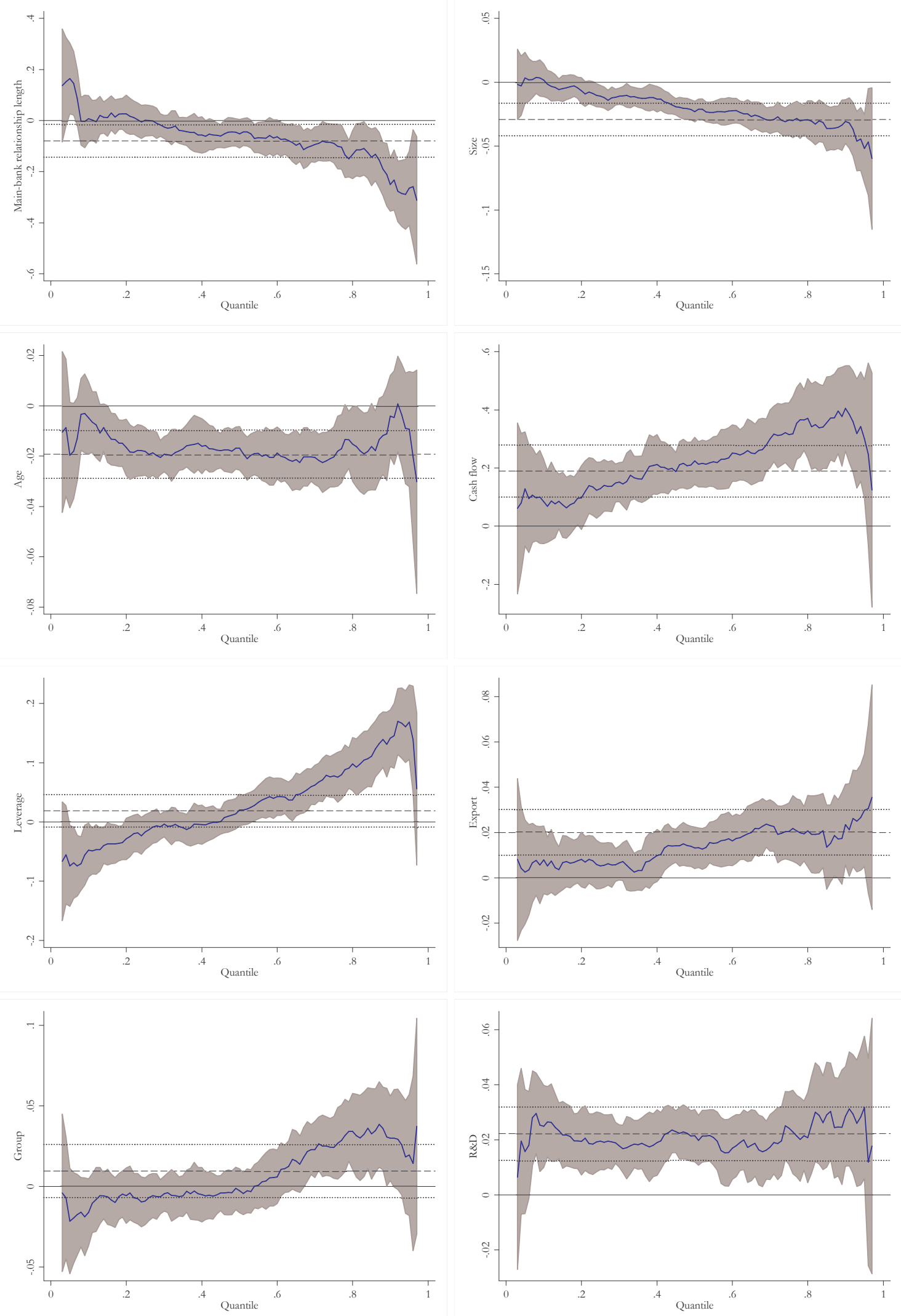

Figure 2C. Small business assets growth. Quantile regression results. 

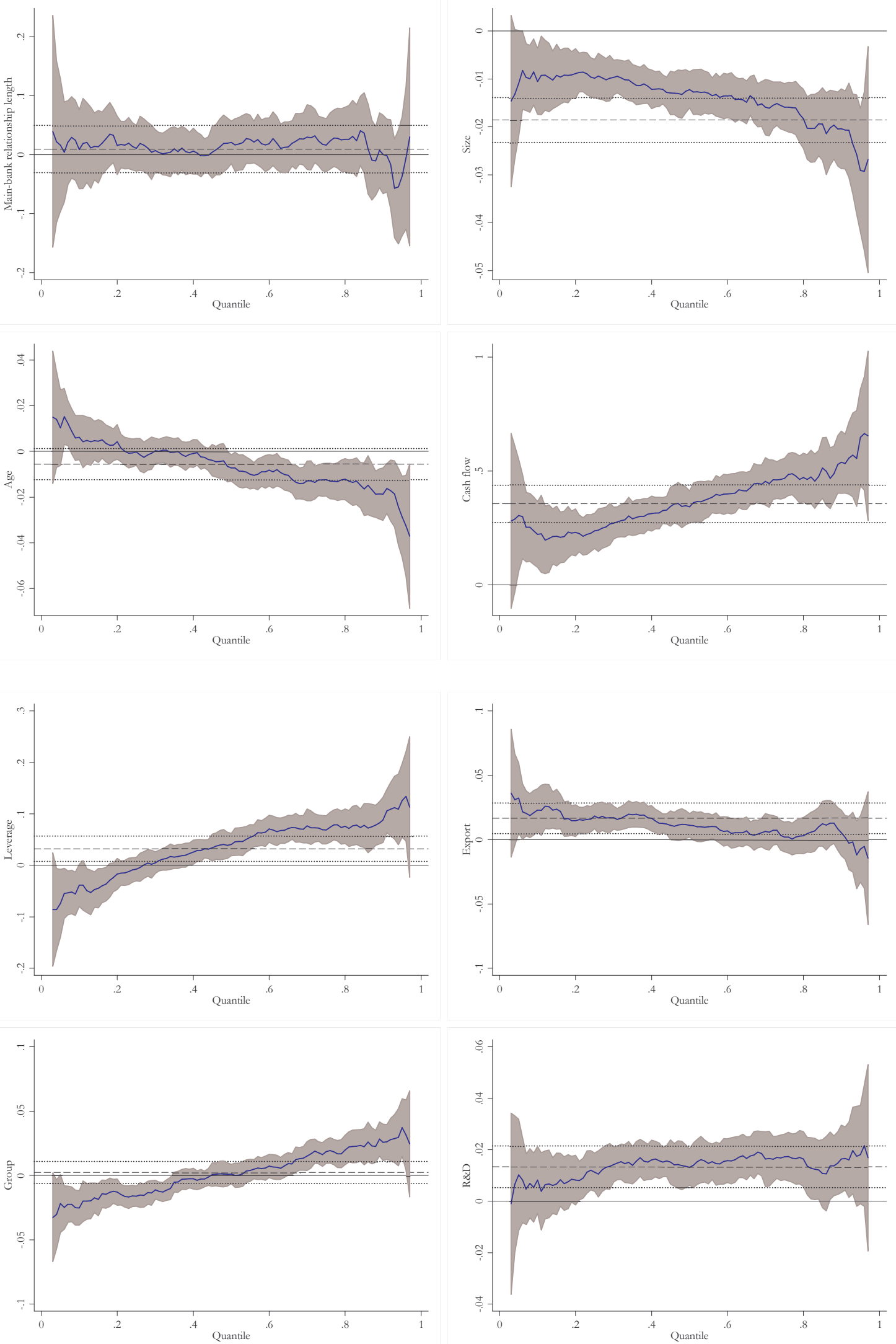

Figure 2D. Medium-large business assets growth. Quantile regression results. 
Table 6. The occupational changing choice. Multinomial logit results.

The table reports multinomial-logit-regression relative risk ratios of standardized independent variables and associated pvalues. The categorical dependent variable takes the value of 1, 2 and 3, accounting respectively for positive, zero and negative employment growth. The base outcome is 2 corresponding to zero growth. Columns (1) and (3) report relative risk ratios and associated p-values of positive growth versus zero growth for small and medium-large business respectively, while columns (2) and (4) report relative risk ratios and associated p-values of negative growth versus zero growth for small and medium-large business respectively. Independent variables are standardized before running the regressions. Being in the same standardized units the relative risk ratios can be compared to assess the relative strength of each of the predictors. We measure relationship length with the main bank as the logarithm of 1 plus the number of years with the main bank minus 3 (divided by 10). Size is the logarithm of the number of employees at the beginning of the period. Age is the logarithm of the number of years since the inception of the firm. Cash flow is the ratio of cash flow to total assets. Leverage is the ratio of debt to total assets. The $(0,1)$ notation means the variable is a dummy taking the value of 1 if the firm presents the specified characteristic and 0 otherwise. All regressions include industrial, geographic and time dummies. $* * *$, ** and $*$ indicate statistically significance at the $1 \%, 5 \%$ and $10 \%$ level, respectively. The table also reports, as a goodness-of-fit test, the pvalues of the $\chi^{2}$-statistic for the Hausman test of independence of irrelevant alternatives and of the F-statistic for the LR test of joint significance of regressors. At the bottom of the table we report the theoretical probability of positive, zero and negative growth for the average firm when the explanatory variable Main-bank relationship length is at its $25^{\text {th }}$ and $75^{\text {th }}$ percentiles.

\begin{tabular}{|c|c|c|c|c|}
\hline & \multicolumn{2}{|c|}{ Panel A: small business } & \multicolumn{2}{|c|}{ Panel B: medium-large business } \\
\hline & $\begin{array}{c}\text { Positive vs } \\
\text { zero growth } \\
\text { (1) }\end{array}$ & $\begin{array}{c}\text { Negative vs } \\
\text { zero growth } \\
\text { (2) }\end{array}$ & $\begin{array}{c}\text { Positive vs } \\
\text { zero growth } \\
\text { (3) }\end{array}$ & $\begin{array}{c}\text { Negative vs } \\
\text { zero growth } \\
\text { (4) }\end{array}$ \\
\hline \multicolumn{5}{|l|}{ Relationship-banking } \\
\hline Main-bank relationship length & $0.875^{* *}$ & 0.962 & 0.949 & $0.857 * * *$ \\
\hline & $(0.028)$ & $(0.575)$ & $(0.325)$ & $(0.008)$ \\
\hline \multicolumn{5}{|l|}{$\underline{\text { Controls }}$} \\
\hline Size & $\begin{array}{c}1.795^{* * *} \\
(0.000)\end{array}$ & $\begin{array}{c}3.807 * * * \\
(0.000)\end{array}$ & $\begin{array}{c}1.415^{* * *} \\
(0.000)\end{array}$ & $\begin{array}{c}2.102 * * * \\
(0.000)\end{array}$ \\
\hline Age & $\begin{array}{c}0.933 \\
(0.290)\end{array}$ & $\begin{array}{c}1.107 \\
(0.187)\end{array}$ & $\begin{array}{c}1.028 \\
(0.641)\end{array}$ & $\begin{array}{c}1.202 * * * \\
(0.005)\end{array}$ \\
\hline Cash flow & $\begin{array}{c}1.192 * * * \\
(0.001)\end{array}$ & $\begin{array}{c}0.786^{* * *} \\
(0.000)\end{array}$ & $\begin{array}{c}1.294 * * * \\
(0.000)\end{array}$ & $\begin{array}{c}0.767 * * * \\
(0.000)\end{array}$ \\
\hline Leverage & $\begin{array}{c}1.285^{* * *} \\
(0.000)\end{array}$ & $\begin{array}{l}0.937 \\
(0.291\end{array}$ & $\begin{array}{c}1.216^{* * *} \\
(0.001)\end{array}$ & $\begin{array}{c}0.939 \\
(0.321)\end{array}$ \\
\hline Export $(0,1)$ & $\begin{array}{c}1.048 \\
(0.322)\end{array}$ & $\begin{array}{c}0.944 \\
(0.295)\end{array}$ & $\begin{array}{c}1.127 * * \\
(0.039)\end{array}$ & $\begin{array}{c}0.988 \\
(0.860)\end{array}$ \\
\hline Group $(0,1)$ & $\begin{array}{c}1.084 \\
(0.218)\end{array}$ & $\begin{array}{c}0.892 \\
(0.183)\end{array}$ & $\begin{array}{c}1.056 \\
(0.246)\end{array}$ & $\begin{array}{c}0.985 \\
(0.779)\end{array}$ \\
\hline$R \& D(0,1)$ & $\begin{array}{c}1.185^{* * *} \\
(0.001)\end{array}$ & $\begin{array}{c}1.013 \\
(0.841)\end{array}$ & $\begin{array}{c}1.038 \\
(0.464)\end{array}$ & $\begin{array}{c}1.050 \\
(0.398)\end{array}$ \\
\hline$\overline{\text { Industry }}$ & $\overline{\text { Yes }}$ & $\bar{Y}$ Yes & $\overline{\text { Yes }}$ & $\bar{Y} \overline{\text { Yes }}-$ \\
\hline $\begin{array}{l}\text { Area } \\
\text { Year }\end{array}$ & $\begin{array}{l}\text { Yes } \\
\text { Yes }\end{array}$ & $\begin{array}{l}\text { Yes } \\
\text { Yes }\end{array}$ & $\begin{array}{l}\text { Yes } \\
\text { Yes }\end{array}$ & $\begin{array}{l}\text { Yes } \\
\text { Yes }\end{array}$ \\
\hline Hausman test & 0.856 & 0.368 & 0.503 & 0.495 \\
\hline Observations & 2478 & 2478 & 2962 & 2962 \\
\hline LR test ( $\mathrm{p}$-value) & 0.000 & 0.000 & 0.000 & 0.000 \\
\hline \multicolumn{5}{|c|}{ The effects of Main-bank relationship-length on the probability of the average firm growing } \\
\hline & \multicolumn{2}{|c|}{ Small business } & \multicolumn{2}{|c|}{ Medium-large business } \\
\hline & 25th percentile & 75th percentile & 25th percentile & 75th percentile \\
\hline Probability of positive growth & 0.350 & 0.323 & 0.491 & 0.500 \\
\hline Probability of zero growth & 0.444 & 0.469 & 0.235 & 0.256 \\
\hline Probability of negative growth & 0.206 & 0.209 & 0.273 & 0.244 \\
\hline
\end{tabular}


Table 7. The occupational intensity choice. Heckit results.

The table reports Heckman two-step procedure results for the two selection models on occupational intensity choice. Columns (1), (3), (5) and (7) report coefficients and associated p-values of the first-stage probit regressions on the selection equations. The dependent variable in columns (1) and (5) ((3) and (7)) is the probability of firms increasing (decreasing) occupation. Three additional variables are included in the selection equations: Roa, a dummy variable taking the value of 1 for firms with a return on assets ratio greater than 0 and 0 otherwise, Default risk, a dummy variable taking if the value of 1 for firms whose one-year probability of default is greater than 0.053 (the median value for the whole sample) and Credit rationing, a dummy variable taking the value of 1 if the firm reports it have desired more credit at the interest rate agreed with the bank and 0 otherwise. The dependent variable in columns (2), (4), (6) and (8) is the employment percentage rate of growth computed as the difference between the logarithms of the respective levels over the length of the period. We measure relationship length with the main bank as the logarithm of 1 plus the number of years with the main bank minus 3 (divided by 10). Size is the logarithm of number of employees at the beginning of the period. Age is the logarithm of the number of years since the inception of the firm. Cash flow is the ratio of cash flow to total assets. Leverage is the ratio of debt to total assets. The $(0,1)$ notation means the variable is a dummy taking the value of 1 if the firm presents the specified characteristic and 0 otherwise. All regressions include industrial, geographic and time dummies. ***, ** and * indicate statistically significant at the $1 \%, 5 \%$ and $10 \%$ level, respectively. The table also reports, as goodness-of-fit test, the p-values of the F-statistic for the Wald test of joint significance of regressors.

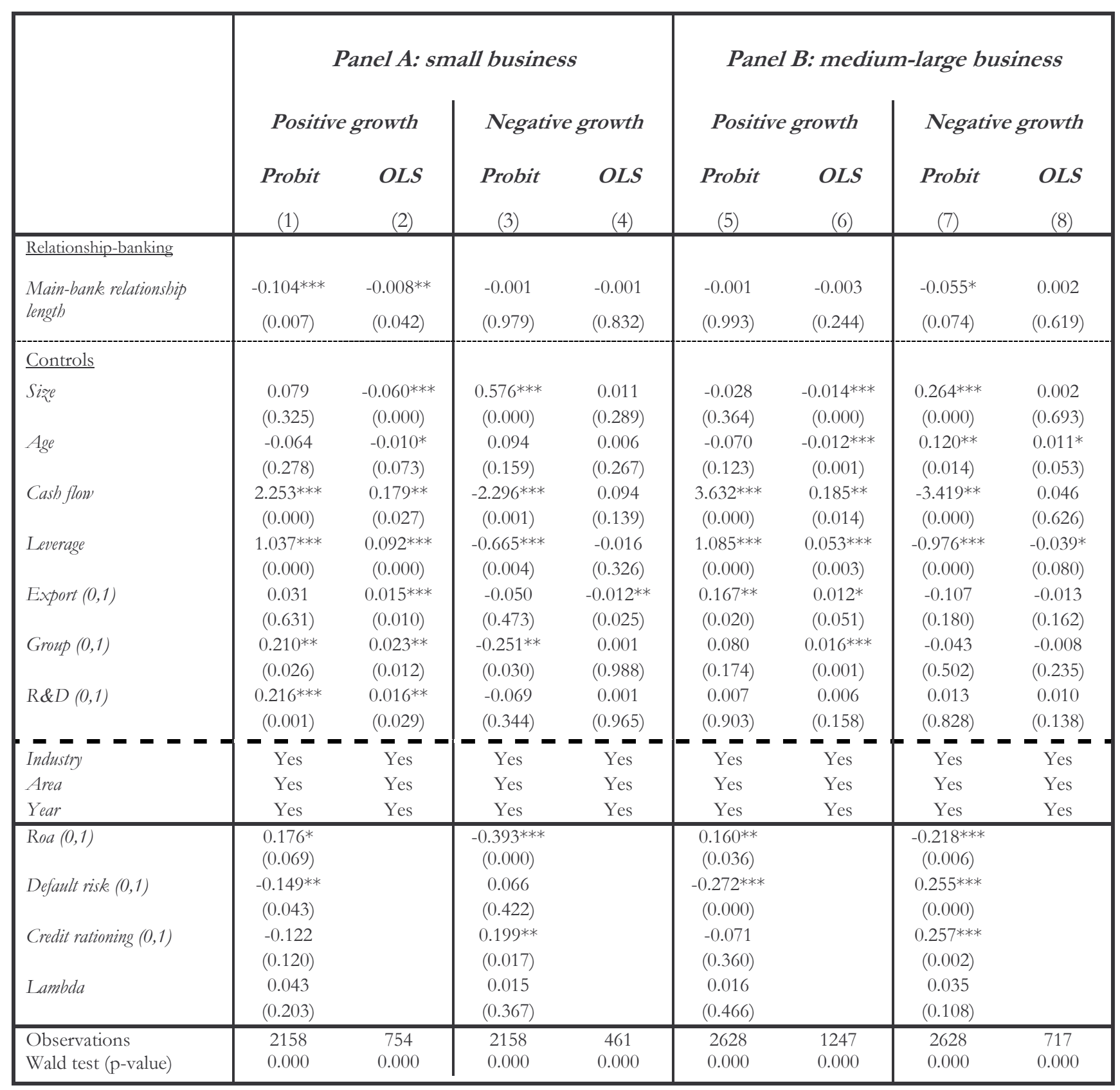

